\title{
SAMODYSCYPLINA I WSZECHSTRONNOŚĆ - CZŁOWIEK KOMUNISTYCZNY W UJĘCIU LENINA
}

\author{
FLORIAN NOWICKI
}

\begin{abstract}
Abstrakt: Artykuł poświęcony jest koncepcji człowieka komunistycznego, jaka wyłania się z pism Włodzimierza Lenina. Autor podkreśla, iż jest ona niekompletna, a w związku z tym niejednoznaczna - prowokująca do zapełniania jej „luk” materiałem nie odnoszącym się bezpośrednio do problematyki społeczeństwa komunistycznego. Rekonstrukcja podąża tropem dwóch pojęć: samodyscypliny i wszechstronności, przy czym duże znaczenie ma proponowane $\mathrm{w}$ artykule rozróżnienie na samodyscyplinę pozytywną i negatywną. Przez samodyscyplinę pozytywną rozumie się ogólnie samodyscyplinowanie się do działań na rzecz społeczeństwa, przy czym za zasadniczy obszar tego rodzaju samodsycypliny uznaje się sferę pracy. Chodzi więc głównie o samodyscyplinowanie się do pracy - konieczne z uwagi na brak mechanizmów przymusu ekonomicznego w komunizmie (urzeczywistniającym zasadę podziału wedle potrzeb, a nie wkładu pracy). Przez samodyscyplinę negatywną rozumie się z kolei powstrzymywanie się od działań szkodliwych społecznie, czyli od tzw. ekscesów konieczne z uwagi na bezpaństwowy charakter społeczeństwa komunistycznego. Samodyscyplina (pozytywna i negatywna) stanowi korelat komunistycznej wolności negatywnej, polegającej (w ujęciu Lenina) na braku jakichkolwiek mechanizmów dyscypliny zewnętrznej, a więc jakiegokolwiek „zarządzania” ludźmi (choćby ultrademokratycznego).
\end{abstract}


Charakteryzując z kolei Leninowskie rozumienie postulatu wszechstronności, autor przywołuje m.in. koncepcję kształcenia politechnicznego (wysuniętą przez Marksa, a rozwijaną przez życiową partnerkę Lenina, Nadieżdę Krupska), odnosząc się także do problemu „inteligentyzacji” proletariatu, a więc postulatu przyswojenia przez proletariat pozytywnych cech inteligencji (rozległość horyzontów, zdolność do samodzielnego, krytycznego „przetwarzania” dorobku kultury ogólnoludzkiej), oddzielonych od jej cech negatywnych (brak umiejętności pracy zespołowej).

Słowa kluczowe: komunizm, człowiek komunistyczny, socjalizm, Marks, Lenin, Krupska, praca, czas wolny, wolność, królestwo wolności. 


\section{Uwagi wstępne}

Zacznijmy od stwierdzenia dość oczywistego faktu: Lenin nigdy nie zajmował się fantazjowaniem na temat komunizmu, a wszystkie jego wypowiedzi dotyczące przyszłego człowieka i społeczeństwa komunistycznego uwikłane są ściśle w konteksty należące do jego teraźniejszości, ewentualnie - stosunkowo bliskiej przyszłości (inna rzecz, że Lenin, w niektórych swoich wypowiedziach, traktuje komunizm jako kwestię stosunkowo bliskiej przyszłości [Lenin 1988i, 306]1). Mówienie zatem o Leninowskiej koncepcji komunizmu, tudzież Leninowskiej koncepcji człowieka komunistycznego, wydawać się może nadużyciem. W niniejszym artykule - wbrew powyższej uwadze - spróbujemy jednakże zastanowić się nad koncepcja człowieka komunistycznego, jaka wyłania się z wypowiedzi Lenina, dotyczących istoty ustroju komunistycznego (różnicy między komunizmem i socjalizmem) a także natury „pracy komunistycznej”. Na marginesie pozostawimy wypowiedzi Lenina dotyczące tzw. moralności komunistycznej - Leninowska „moralność komunistyczna” wydaje się bowiem raczej moralnością człowieka walczącego o komunizm, a więc człowieka okresu przejściowego, niż człowieka komunistycznego, czyli człowieka żyjącego w zbudowanym już społeczeństwie komunistycznym („U podstaw moralności komunistycznej leży walka o umocnienie i doprowadzenie do końca budowy komunizmu" [Lenin 1988i, 302]). Już w tym miejscu wypada jednak zaznaczyć, iż koncepcja będąca przedmiotem naszych rozważań jest konstrukcją dalece niekompletna, nie rozstrzygającą wielu istotnych problemów, i tym samym prowokująca interpretatorów/ki do zapełniania jej „luk” materiałem zaczerpniętym $\mathrm{z}$ wypowiedzi Lenina dotyczących zupełnie innych zagadnień. Pokusie tej nie oprzemy się również w niniejszym artykule.

Człowiek komunistyczny ma być - według Lenina - człowiekiem, po pierwsze, samodyscyplinującym się, po drugie, wszechstronnie rozwiniętym. Zacznijmy od pierwszej kwestii. Lenin przeciwstawia samodyscyplinę (dyscyplinę świadoma) dyscyplinie zewnętrznej - dyscyplinie bata i głodu społeczeństw klasowych (Lenin 1988f, 358; Lenin 1988h, 13) (a także socjalistycznej dyscyplinie kontroli administracyjnej i bodźców ekonomicznych). Definicję samodyscypliny znajdujemy u Krupskiej. „Skąd - pyta Krupska - bierze się

\footnotetext{
1 „Pokolenie, którego przedstawiciele liczą obecnie około 50 lat, nie może spodziewać się, że zobaczy społeczeństwo komunistyczne. Do tego czasu pokolenie to wymrze. Natomiast pokolenie, które liczy obecnie 15 lat - nie tylko zobaczy społeczeństwo komunistyczne, ale i samo będzie to społeczeństwo budowało. i powinno ono wiedzieć, że zadaniem całego jego życia jest budowanie tego społeczeństwa" (Lenin 1988i, 306).
} 
dobrowolna dyscyplina? Z pełnej świadomości, że trzeba postąpić właśnie tak, a nie inaczej”. Co skłania chłopca do nocnej, dziesięciokilometrowej wyprawy po lekarstwo dla matki? „Miłość do matki i świadomość, że lekarstwo ją uratuje. Więc i pionierzy muszą zdawać sobie jasno sprawę z tego, co robią. Wówczas będzie się w nich również umacniać dobrowolna dyscyplina” (Krupska 1951, 102).

Lenina interesują dwa aspekty komunistycznej samodyscypliny. Pierwszy z nich dotyczy pracy (komunistyczny stosunek do pracy), drugi - przestrzegania elementarnych norm współżycia społecznego (powstrzymywanie się od „ekscesów”). Państwo a rewolucja (pisane w 1917 roku) dostarcza interesującego materiału do analizy poglądów Lenina na drugi z wyróżnionych aspektów komunistycznej samodyscypliny. Aspektowi pierwszemu - pracy komunistycznej - poświęcony jest natomiast tekst z 1919 roku, Wielka inicjatywa (O bohaterstwie robotnikón na zapleczu. Z okazji „komunistycznych subotników”). Zbliżone poglądy na pracę komunistyczna przedstawia Lenin również w innych tekstach pochodzących z tego samego okresu, poświęconych analizie zjawiska „komunistycznych subotników”.

\title{
2. Komunizm w świetle pracy Państwo i rewolucja
}

Leninowska charakterystyka komunizmu z Państwa a rewolucji przypisuje mu dwa zasadnicze atrybuty:

- obowiązywanie komunistycznej zasady podziału: od każdego/ej wedle możliwości, każdemu/ej wedle jego/ej potrzeb (przeciwstawianej socjalistycznej zasadzie podziału według pracy);

- bezpaństwowość (przerastanie socjalizmu w komunizm obejmuje proces obumierania państwa).

\begin{abstract}
Państwo będzie mogło obumrzeć całkowicie wtedy, kiedy społeczeństwo urzeczywistni zasadę: „każdy według swoich zdolności, każdemu według jego potrzeb”, tj. kiedy ludzie do takiego stopnia przywykną do przestrzegania zasadniczych reguł współżycia i kiedy praca ich będzie tak wydajna, że dobrowolnie pracować będa wedtug zdolności. „Ciasny horyzont prawa burżuazyjnego”, nakazujący rachować z zajadłością Szajloka, czy aby nie pracuje się pół godziny dłużej niż inni, nie zarabia mniej niż inni - ten ciasny horyzont zostanie wówczas przekroczony. Podział produktów nie będzie wtedy wymagał regulowania przez społeczeństwo ilości otrzymywanych przez każdego produktów; każdy będzie swobodnie brał „,według potrzeb” (Lenin 1951, 214).
\end{abstract}

Atrybut pierwszy bierze Lenin bezpośrednio z Krytyki Programu Gotajskiego (napisanej przez Marksa w 1875 roku, a opublikowanej przez Engelsa w 1891). Leninowskie rozróżnienie 
socjalizmu i komunizmu - o tyle, o ile wskazuje na odmienność obowiązujących w socjalizmie i komunizmie zasad podziału, skorelowanych z odpowiednimi właściwościami antropologicznymi - odpowiada dokładnie Marksowskiemu rozróżnieniu niższej i wyższej fazy społeczeństwa komunistycznego.

[W socjalizmie - przyp. FN] Całe społeczeństwo będzie jednym biurem i jedną fabryką z równą pracą i równą płacą.

Ale ta dyscyplina „fabryczna”, która proletariat po zwycięstwie nad kapitalistami, po obaleniu wyzyskiwaczy rozciagnie na całe społeczeństwo, nie jest bynajmniej ani naszym ideałem, ani naszym celem ostatecznym, lecz jedynie szcreblem niezbędnym do radykalnego oczyszczenia społeczeństwa od nikczemności i ohydy wyzysku kapitalistycznego $i$ do dalszego marszu naprzód (Lenin 1951, 218).

Lenin zapowiada tu obumieranie dyscypliny fabrycznej w miarę przerastania socjalizmu w komunizm. Przez dyscyplinę fabryczną nie należy jednak - w tym kontekście - rozumieć ścisłej koordynacji działań wielu ludzi w ramach kooperacji złożonej - implikującej istnienie funkcji „dyrygenta” (Marks 1983, 592)2, tudzież „zasadę autorytetu” (Engels 1969a, 341)3. Leninowi możemy, jak sądzę, przypisać pogląd, iż o przyszłych losach tego rodzaju dyscypliny decydować będą obiektywne względy techniczne. Tutaj zaś chodzi o taką dyscyplinę, która mogłaby obumierać w miarę obumierania określonych cech „antropologicznych”, będących dziedzictwem epoki społeczeństw klasowych. Lenin ma tu w gruncie rzeczy na względzie dyscypline zewnetržnq w jej specyficznie socjalistycznej formie, a więc dyscyplinę wymuszaną skrupulatnym normowaniem, ewidencjonowaniem i premiowaniem. W epoce socjalizmu całe społeczeństwo będzie nie tylko jedną wielką fabryką, ale także jednym wielkim biurem - normującym ludzką pracę i ewidencjonującym jej rezultaty, by wszyscy/tkie pracownicy/czki mogli/ły otrzymywać wynagrodzenia stosowne

„[...] we wszelkich pracach, w których współdziała wiele jednostek, powiązanie i jedność procesu muszą być nieodzownie reprezentowane przez jedną kierującą wolę tudzież przez funkcje, które nie dotyczą prac cząstkowych, lecz całokształtu działalności warsztatu, podobnie jak to widzimy u dyrygenta orkiestry. Jest to praca produkcyjna, która musi być wykonywana przy każdym skombinowanym sposobie produkcji”' (Marks 1983, 592).

3 „[...] niezależnie od tego, czy będą one [szczegółowe zagadnienia, dotyczące sposobu produkcji, dystrybucji materiałów itd. - przyp. FN] rozstrzygane przez delegata postawionego na czele każdego działu produkcji czy też, jeśli byłoby to możliwe, głosem większości, wola jednostki musi się zawsze podporządkować: a to oznacza, że zagadnienia te rozwiązywane będa autorytatywnie. Mechaniczny automatyzm wielkiej fabryki jest o wiele bardziej tyrański niż jacykolwiek drobni kapitaliści zatrudniający robotników. Nad bramami tych fabryk, przynajmniej jeśli idzie o godziny pracy, można napisać: Porzućcie wsz̨elka autonomie, wy, którayy tu wchodzicie! [...] Chcieć likwidacji autorytetu w wielkim przemyśle - to tyle co chcieć likwidacji wielkiego przemysłu - zniszczenia przędzalnictwa parowego dla powrotu do kołowrotka" (Engels 1969a, 341). 
do ilości i jakości wydatkowanej przez nich/nie pracy. Socjalistyczne biuro zastąpi kapitalistyczny rynek z żywiołowo działającym prawem wartości, by... urzeczywistnić prawo wartości w jego czystej postaci. Postępowe przemiany antropologiczne nie zdołają wyrugować przemysłowych „dyrygentów” - o ile będa oni niezbędni ze względów technicznych. Moga one jednakże doprowadzić do zamknięcia socjalistycznego „biura”. Gdyludzie nauczą się pracować na miarę swoich możliwości (a nie poniżej swych możliwości) bez ekonomicznych „marchewek” w postaci wyższych wynagrodzeń, cała buchalteria związana z normowaniem i ewidencjonowaniem, a więc kontrolowaniem, okaże się przeżytkiem. Socjalistyczna dyscyplina biurowa zastapiona zostanie komunistyczną samodyscypliną (Lenin powtarza w Państwie a rewolucï argumentację Marksa odnośnie do tego, iż pozornie sprawiedliwa zasada równej płacy za równą pracę, czyli wyższej płacy za lepsza/dłuższą pracę, która urzeczywistniona zostanie w socjalizmie, jest zasadą niesprawiedliwą, jeśli uwzględnić fakt, że ludzie nie są sobie równi pod względem posiadanych „zdolności”; komunizm - rozrywając związek między wkładem pracy a wynagrodzeniem - realizuje więc wyższą formę sprawiedliwości niż sprawiedliwość socjalistyczna, będąca w istocie realizacją burżuazyjnego prawa wartości).

Leninowską innowacje - przynajmniej w stosunku do „litery” Krytyki Programu Gotajskiego - stanowi atrybut drugi: bezpaństwowość. W tym zakresie Lenin podąża raczej za anarchizująca terminologią Engelsa, mówiącego explicite o obumieraniu państwa (Engels 1972a, 313) i odesłaniu go do muzeum starożytności (Engels 1969b, 191), niż za Marksem poprzestającym na bardziej umiarkowanej formule depolityzacji władzy państwowej z Nędzy filozofii (Marks 1962, 198) i Manifestu komunistycznego (Engels i Marks 1962, 536), który w Krytyce Programu Gotajskiego mówi nawet o przyszłej „państwowości społeczeństwa komunistycznego" (Marks 1972, 33).

Obydwa atrybuty łączy to, iż implikują one człowieka samodyscyplinującego się. Komunistyczna zasada podziału implikuje bezpośrednio określony rodzaj komunistycznej samodyscypliny: samodyscyplinowanie się do pracy. Samodycyplinowanie się do pracy możemy uznać za kluczową odmianę samodyscypliny pozytywnej, polegającej na samodyscyplinowaniu się do rozmaitych działań pozytywnych, mających na celu dobro wspólne. Samodyscyplinę pozytywną należy odróżnić od samodyscypliny negatywnej: samodyscyplinowania się do unikania działań społecznie szkodliwych, tzw. ekscesów. Atrybut drugi - bezpaństwowość - implikuje człowieka, który nie tylko samodyscyplinuje się do pracy 
(i innych działań pozytywnych), ale ponadto: dobrowolnie powstrzymuje się od ekscesów (co czyni bezużytecznym wszelki aparat, mający chronić społeczeństwo przed jednostkami dopuszczającymi się ekscesów).

Rozpatrzmy oddzielnie dwie odmiany komunistycznej samodyscypliny, do których odsyła Leninowska charakterystyka komunizmu (syntetyzująca Marksowski wątek komunistycznej zasady podziału z Engelsowskim wątkiem obumierania państwa): samodyscyplinę pozytywną (w odniesieniu do pracy) i samodyscyplinę negatywną (unikanie ekscesów).

\section{Komunistyczna samodyscyplina pozytywna}

Przejście do komunistycznej zasady podziału (czyli do interesującej nas tu samodyscypliny pozytywnej) wymaga według Marksa i Lenina zaistnienia co najmniej trzech przesłanek: zaniku przeciwieństwa między pracą fizyczną i umysłową, masowego uwewnętrznienia potrzeby pracy i radykalnego wzrostu materialnego dobrobytu:

\footnotetext{
W wyższej fazie społeczeństwa komunistycznego, kiedy zniknie ujarzmiające człowieka podporządkowanie podziałowi pracy, a przez to samo zniknie też przeciwieństwo pomiędzy pracą fizyczną a umysłowa; kiedy praca stanie się nie tylko źródłem utrzymania, ale najważniejsza potrzebą życiowa; kiedy wraz ze wszechstronnym rozwojem jednostek wzrosną również ich siły wytwórcze, a wszystkie źródła zbiorowego bogactwa popłyną obficiej - wówczas dopiero będzie można całkowicie wykroczyć poza ciasny horyzont prawa burżuazyjnego i społeczeństwo będzie mogło wypisać na swym sztandarze: Każdy według swych zdolności, każdemu według jego potrzeb! (Marks 1972, 24).
}

Podążmy tropem przesłanki drugiej (masowe uwewnętrznienie potrzeby pracy). Na pierwszy rzut oka sprawa jest oczywista: jeżeli ludzie pracować będa gwoli zaspokojenia potrzeby pracy (a nie wyłącznie dla uzyskania określonego wolumenu dóbr konsumpcyjnych), będą oni pracowali na miarę swoich możliwości (a nie poniżej swych możliwości) - pomimo braku skłaniających ich ku temu bodźców o charakterze ekonomicznym. Wyłania się jednak następujące pytanie: czy wchodząca tu w grę - jako przesłanka komunistycznych stosunków podziału - potrzeba pracy jest tą samą potrzebą twórczej eksterioryzacji - "gatunkową" potrzebą „przetwarzania świata przedmiotowego”, „wolnej, świadomej działalności” - która ma na względzie Marks, gdy piętnuje zjawisko alienacji pracy? (Marks 1976, 550-554).

Odpowiedź pozytywna zakłada, iż to właśnie praca stanowić będzie w komunizmie podstawową formę ludzkiej samorealizacji, twórczości, eksterioryzacji; że to właśnie czas 
pracy będzie czasem zaspokajania „najważniejszej potrzeby życiowej”, czasem ludzkiego „samourzeczywistniania się”, stymulowania i stosowania specyficznie ludzkich „zdolności”; że to właśnie praca stanie się obszarem realizacji Marksowskiej prognozy o utożsamieniu rozwoju uzdolnień rodzaju ludzkiego z rozwojem poszczególnych jednostek (Marks 1981, 140). Zaspokajając potrzebę pracy, obywatele/ki społeczeństwa komunistycznego zaspokajać będą w gruncie rzeczy metapotrzebę życia specyficznie ludzkiego. Konieczne wydaje się tu jednak założenie „atrakcyjności” pracy komunistycznej, a więc założenie, iż praca stanie się w przyszłości dogodnym terenem ludzkiej twórczości, swobodnego rozwoju „energii fizycznej i duchowej”, formowania (wszechstronnie) rozwiniętych osobowości. Mówiąc w tym kontekście o „atrakcyjności” przyszłej pracy, nie mamy zatem na względzie jej hipotetycznego przekształcenia w rozrywkę, ale - przeciwnie - jej przekształcenie w „diabelnie poważny trud” ludzkiego „samourzeczywistniania się” (Marks 1986, 491).

Sformułujmy jednak interpretację alternatywną: potrzeba pracy, o której piszą Marks i Lenin jako o przesłance komunistycznych stosunków podziału, nie jest (egocentryczna) potrzebą twórczej eksterioryzacji, ale (altruistyczna) potrzebą działania dla dobra ogółu, którą można uznać za istotną składową - kolektywistycznie zorientowanego - światopoglądu komunistycznego.

A co w takim razie - wypada zapytać - z potrzebą twórczej eksterioryzacji? Z pism Marksa można wywieść koncepcję, w świetle której potrzeba twórczej eksterioryzacji zaspokajana będzie w komunizmie po pracy (np. w formie amatorskiej działalności naukowej, artystycznej i sportowej), a więc w komunistycznym „królestwie wolności” - i to właśnie w „królestwie wolności” (czas wolny) hartować się będą wszechstronnie rozwinięte osobowości ludzi komunistycznych. Na gruncie tej koncepcji kwestia skracania czasu pracy „do stale spadającego minimum” (zob. np.: Marks 1986, 575, 578-579) nabiera znaczenia absolutnie pryncypialnego. Skoro długość czasu wolnego stanowi zasadniczą miarę rozwoju „królestwa wolności”, wytwarzanie czasu wolnego (dzięki rozwijaniu techniki) okazuje się równoznaczne z wytwarzaniem komunistycznej formy „bogactwa”. Koncepcja ta - dodajmy - nie wymaga przyjmowania wątpliwego założenia o „atrakcyjności” pracy komunistycznej w zupełności wystarcza tu założenie o jej nieszkodliwości (braku deformującego wpływu na fizyczno-intelektualny rozwój jednostek dzięki postulowanemu przez Marksa zniesieniu dawnego podziału pracy). 
Autorytet Marksa nie pozwala jednoznacznie rozstrzygnąć wchodzącego tu w grę dylematu. Marks ujmuje (przyszła) pracę jako formę „samourzeczywistniania” się podmiotu, sugerując nawet, iż „produkcja w imię produkcji oznacza właściwie rozwój ludzkich sił wytwórczych, a więc rozwój bogactwa natury ludžkiej jako cel sam w sobie” (Marks 1986, 238, 491; Marks 1981, 139-140).

$\mathrm{Za}$ istotna przesłankę takiego stanowiska można uznać formułowane przez Marksa prognozy odnośnie do tendencji rozwojowych wielkiego przemysłu, który w coraz większym stopniu wymagać będzie ,jednostek wszechstronnie rozwiniętych”: „Wielki przemysł czyni sprawą życia i śmierci” „zastąpienie jednostki cząstkowej, prostego nosiciela jakiejś cząstkowej funkcji społecznej, przez jednostkę wszechstronnie rozwiniętą, dla której różne funkcje społeczne są kolejno po sobie następującymi formami jej działalności” (Marks 1968, 580, 581). Na hipotezie tej wspiera się postulowany przez Marksa ogólnikowo system pedagogiczny:

Z systemu fabrycznego, jak to Robert Owen wykazał szczegółowo, wyrosły zalążki systemu wychowawczego przyszłości, który wszystkie dzieci powyżej pewnego wieku obejmie wychowaniem łączacym prace produkcyjną z nauką i gimnastyka, nie tylko w celu zwiększenia produkcji społecznej, lecz także w celu uformowania wszechstronnie rozwiniętych ludzi (Marks 1968, 575-576).

Marks przewiduje intelektualizację, unaukowienie przyszłej pracy produkcyjnej, jej przekształcenie w „,czynność nadzoru i regulowania” (Marks 1986, 576): „ustanie praca, którą człowiek sam się trudził, a którą będzie mógł powierzyć rzeczom, by ją za niego wykonywały" (Marks 1986, 238).

W produkcji materialnej praca może przybrać podobny [wolny, atrakcyjny - przyp. FN] charakter tylko jeżeli: 1) posiada charakter społeczny, 2) mając charakter naukowy, jest zarazem pracą ogólną, nie wysiłkiem człowieka, działającego jak wytresowana siła przyrody, lecz podmiotem, występującym w procesie produkcji już nie w postaci przyrodniczej, żywiołowej, lecz jako działalność regulująca wszystkie siły przyrody (Marks 1986, 491).

Z drugiej strony, tenże sam Marks, wychodząc z niejednokrotnie formułowanego założenia, iż to właśnie czas wolny stanowi zasadnicza przestrzeń rozwoju człowieka (uzdolnień, sił twórczych/wytwórczych jednostek) (Marks 1986, 575, 578-579; Marks 1966, 109-110, 298 
300), stwierdza explicite, że dopiero poza granicami produkcji materialnej „rozpoczyna się rozwój sił ludzkich jako cel sam w sobie, prawdziwe królestwo wolności” (Marks 1984, 560_ $561)$.

Co na to Lenin? Lenin nie podejmuje nigdzie problemu „miejsca” zaspokajania potrzeby twórczej eksterioryzacji w komunizmie (ani też nie zajmuje się samą tą potrzeba, jak również alienacją pracy) - odpowiada on jednak explicite na pytanie o naturę potrzeby pracy (jako przesłanki stosunków komunistycznych), łącząc ją z ogólniejszą potrzebą działania na rzecz dobra ogółu (a nie z potrzebą twórczej eksterioryzacji):

\begin{abstract}
W węższym i ściślejszym tego słowa znaczeniu praca komunistyczna jest to bezpłatna praca na rzecz społeczeństwa, praca wykonywana nie ze względu na spełnienie określonego obowiązku, nie w celu uzyskania prawa do otrzymania pewnych produktów, nie według $\mathrm{z}$ góry ustalonych $\mathrm{i}$ zatwierdzonych norm, lecz praca dobrowolna, praca niezależna od norm, praca wykonywana nie $z$ uwagi na wynagrodzenie, nie przewidująca wynagrodzenia, wynikająca z nawyku do pracy dla dobra ogółu i oparta na świadomym stosunku (który stał się nawykiem) do konieczności pracy dla dobra ogółu, praca jako potrzeba zdrowego organizmu (Lenin 1988d, 302).
\end{abstract}

Potrzeba pracy nie jest tu ujmowana jako rezultat hipotetycznej „atrakcyjności” pracy komunistycznej (w wyłuszczonym wcześniej sensie), ale jako wynik internalizacji określonego światopoglądu, korelat „świadomego stosunku (który stał się nawykiem) do konieczności pracy dla dobra ogółu”. Owszem, w tym ujęciu praca stanowi zarazem „potrzebę zdrowego organizmu" - nie spotykamy tu jednak sugestii, jakoby miała ona cokolwiek wspólnego z potrzebą działalności autentycznie twórczej, tudzież samorozwojowej. Człowiek komunistyczny, pracując, nie tyle się więc eksterioryzuje, ile samodyscyplinuje - tzn. działa zgodnie z zaleceniami uwewnętrznionego światopoglądu. Ewentualna przykrość związana z poddawaniem samego/ej siebie tego rodzaju dyscyplinie kompensowana jest nie satysfakcja płynąca z uprawiania działalności twórczej (możliwością przeglądania się w swych „dziełach”) oraz wynikającymi z uprawiania takiej działalności profitami osobowościowymi (rozwinięta osobowość jako komunistyczna forma „bogactwa”), ale (zdeterminowaną światopoglądowo) satysfakcją z działania na rzecz dobra ogółu. Co więcej, ponieważ aktywność fizycznointelektualna (której formę stanowić może praca) jest naturalną potrzebą organizmu pracowanie pozwala uniknać „przykrości” związanej z ewentualną bezczynnością fizycznointelektualną. 
Rozważając Leninowską definicje pracy komunistycznej, musimy pamiętać o tym, iż do jej sformułowania sprowokowały Lenina narodziny inicjatywy komunistycznych subotników:

I oto ci głodni robotnicy, otoczeni zewsząd złośliwa, kontrrewolucyjną agitacja burżuazji, mienszewików i eserowców, urządzaja „komunistyczne subotniki”, pracuja w godzinach nadliczbowych bez żadnej zaplaty i osiagają olbraymi wzrost wydajności pracy, mimo że są znużeni, przemęczeni, wyczerpani wskutek niedojadania. Czyż nie jest to największe bohaterstwo? Czyż nie jest to początek zwrotu mającego powszechnodziejowe znaczenie? (Lenin 1988h, 20)

Jest rzeczą absolutnie oczywistą, iż warunki i charakter pracy wykonywanej w ramach subotników nie pozwalały traktować tej pracy w kategoriach pracy twórczej (czy pracy radosnej), a jedynie w kategoriach pracy ofiarnej, heroicznej, bohaterskiej. Rozpaczliwe warunki wszelkiej pracy wykonywanej w owym czasie (1920 r.), zarówno dobrowolnej, jak i obowiązkowej, zniechęcały raczej do fantazjowania o rozkoszach (przyszłej) pracy i jej zbawiennym wpływie na ludzką osobowość; z drugiej strony, chęć docenienia tej heroicznej inicjatywy głodujących i wyczerpanych robotników niewątpliwie zachęcała Lenina do teoretycznego uzasadniania zaszczytnej nazwy: „subotniki komunistyczne”, a więc również do ujmowania owych subotników jako „pędów komunizmu”.

Z Leninowskiej refleksji nad subotnikami wyrasta - niejako mimochodem - pewna wizja przyszłego komunizmu, odrębna o dwóch innych, dających się wywieść z pism Marksa, co więcej, w jakimś zakresie rozmijająca się także z „duchem” tekstu Państwo a rewolucja.

Wizja pierwsza - oparta na optymistycznych prognozach odnośnie do atrakcyjności przyszłej pracy - utożsamia komunistyczną praxis z pracą niewyalienowana, twórczą i unaukowioną (uwolnioną od żmudnego, nietwórczego trudu - powierzonego przyrodzie), pracą stymulującą wszechstronny rozwój osobowości (co zakłada obalenie starego podziału pracy, skazującego robotnika/cę na dożywotnią, jednostronną specjalizację). Wizja druga nadająca pryncypialny charakter postulatowi znaczącego skrócenia czasu pracy - lokalizuje komunistyczną formę życia w królestwie czasu wolnego, w sferze amatorskiej działalności artystycznej, naukowej i sportowej. Wizja Leninowska, wyrastająca z refleksji nad subotnikami, rozmija się z wizja pierwszą o tyle, o ile nie implikuje optymistycznych prognoz związanych z radykalną dezalienacja pracy, i zbliża się do niej - o tyle, o ile za kluczowy atrybut człowieka komunizmu uznaje określony stosunek do pracy i ogólniej - identyfikuje „cnoty” człowieka komunistycznego z „cnotami” dobrego/ej robotnika/cy (zaznaczmy 
jednak, iż nie są to te same cnoty, które należałoby przypisywać robotnikowi/cy twórczo się eksterioryzującemu/ej).

W świetle Leninowskiej wizji komunizmu, wyrastającej z refleksji nad subotnikami, istotę życia komunistycznego stanowi nie eksterioryzacja, ale samodyscyplina (w tym zakresie jest to wizja zgodna z duchem Państwa a rewolucji), przy czym na plan pierwszy wysuwa się tu kwestia komunistycznego stosunku do pracy (samodyscyplinowanie się do pracy). Akcentem nowym (w stosunku do „ducha” wizji z Państwa a rewolucji) jest swoista heroizacja pracy komunistycznej, łączenie jej z autentycznie przeżywaną „troską” o dobro wspólne, z walka między uczuciami kolektywistycznymi a starymi odruchami indywidualistycznymi. Wątek heroiczny zostaje jednakże zrównoważony założeniem, iż proletariat - jako klasa wyszkolona w kapitalistycznej dyscyplinie fabrycznej - bezboleśnie podporządkuje się nowej dyscyplinie pracy dla dobra ogółu, że - ze względu na przebytą szkołę kapitalistycznej fabryki - jest on klasą szczególnie predestynowaną do wykształcenia w swych szeregach samodyscypliny (czyli zrzucenia jarzma dyscypliny zewnętrznej). Jednym słowem, ewentualny heroizm człowieka komunistycznego będzie heroizmem łatwym w realizacji - realizację jego imperatywów ułatwiać będzie bowiem przebyty (w społeczeństwie kapitalistycznym) trening.

\begin{abstract}
Komunistyczna organizacja pracy społecznej [...], ku której pierwszym krokiem jest socjalizm, opiera się $[\ldots]$ - i im dalej, tym bardziej opierać się będzie na niewymuszonej i świadomej dyscyplinie samych ludzi pracy, którzy zrzucili jarzmo zarówno obszarników, jak kapitalistów.

Ta nowa dyscyplina nie spada z nieba i nie rodzi się z pobożnych życzeń, wyrasta ona z materialnych warunków wielkiej produkcji kapitalistycznej - i tylko z nich. Bez tych warunków jest ona niemożliwa. Nosicielem zaś tych materialnych warunków, ich szerzycielem jest określona klasa historyczna, stworzona, zorganizowana, zespolona, wyszkolona, oświecona, zahartowana przez wielki kapitalizm. Klasą ta jest proletariat (Lenin 1988h, 13).
\end{abstract}

Proletariacka samodyscyplina komunistyczna znajduje swój wyraz w - uwewnętrznionej trosce szeregowych robotników o zwiększenie wydajności pracy, w ich pracy na rzecz ludzi „dalekich”:

Komunizm - to wyższa w porównaniu z kapitalistyczną wydajność pracy robotników pracujących z własnej woli, świadomych, zjednoczonych, posługujących się najnowszą 
technika. Komunistyczne subotniki są niezwykle cenne, jako faktyczne zapoczątkowanie komunizmu [...]

Komunizm zaczyna się tam, gdzie pojawia się ciężki trud, troska szeregonych robotnikón o zwiększenie wydajności pracy, o ochronę każdego puda z̧boża, wegla, żelaza i innych produktów, które otrzymuja nie ci, którzy osobiście pracują i nie ich „bliscy”, ale „dalecy”, czyli całe społeczeństwo... (Lenin 1988h, 20-21).

Założeniem systemu socjalistycznego jest niedorozwój tego rodzaju samodyscypliny, kompensowany przez najściślejszą ewidencję i kontrolę (umożliwiająca prawidłowe działanie „bodźcowego” systemu wynagradzania pracy), natomiast przesłankę komunizmu stanowi powszechne przyzwyczajenie ludzi do wykonywania społecznych obowiązków bez aparatu przymusu:

Socjalizm zakłada pracę bez pomocy kapitalistów, społeczna pracę $\mathrm{w}$ warunkach najściślejszej ewidencji, kontroli i nadzoru ze strony zorganizowanej awangardy, przodującej części ludzi pracy; musi być przy tym określana zarówno miara pracy, jak i wynagrodzenie za nią. Określanie to jest konieczne, ponieważ po społeczeństwie kapitalistycznym mamy takie pozostałości i takie nawyki, jak praca w rozdrobnieniu, brak zaufania do gospodarki społecznej, stare nawyki drobnego gospodarza, które przeważaja we wszystkich krajach chłopskich. Wszystko to jest sprzeczne z gospodarką prawdziwie komunistyczną. Komunizmem zaś nazywamy taki porządek, w którym ludzie przyzwyczajaja się do wykonywania obowiązków społecznych bez specjalnego aparatu przymusu, kiedy bezpłatna praca dla dobra ogółu staje się zjawiskiem powszechnym (Lenin 1988g, 31-32).

Kształtowanie komunistycznego stosunku pracy wymaga wykorzenienia mentalności indywidualistycznej. Formułując to zadanie, Lenin uderza w patetyczny ton:

Toteż składamy sobie nawzajem [...] przyrzeczenie, że [...] wytrwamy w tej najtrudniejszej walce - w walce z siła przyzwyczajenia - że pracować będziemy bez wytchnienia całe lata i dziesięciolecia. Pracować będziemy, aby wyplenić przeklęta zasadę: „każdy za siebie, jeden bóg za wszystkich”, aby wyplenić zwyczaj, że pracę uważa się jedynie za powinność i że za pracę uzasadnioną uważa się jedynie pracę opłaconą według określonej normy. Pracować będziemy, aby wpoić w świadomość, w przyzwyczajenie, uczynić codziennym nawykiem mas regułę: „wszyscy za jednego, jeden za wszystkich”, regułę: „od każdego według swych zdolności, każdemu według jego potrzeb”, aby wprowadzać stopniowo, lecz nieugięcie komunistyczną dyscyplinę i komunistyczną pracę. 
[...] Lata i dziesięciolecia będziemy pracować nad stosowaniem subotników, nad ich rozwijaniem, upowszechnianiem, usprawnianiem, nad tym, by stały się one zwyczajem. Doprowadzimy do tego, że praca komunistyczna zwycięży! (Lenin 1988c, 103-104).

Praca komunistyczna (zapoczątkowana przez subotniki) jest więc przez Lenina zabarwiana silnymi pierwiastkami moralnymi - jako forma realizacji pięknej zasady: „wszyscy za jednego, jeden za wszystkich”, przeciwstawianej „przeklętej” zasadzie: „każdy za siebie”. Można by jednak zapytać, w jakiej relacji pozostaje koncepcja komunizmu, sprowadzająca jego istotę do pracy komunistycznej i moralizująca komunistyczny stosunek do pracy, do głoszonego przez Lenina pryncypialnego postulatu skracania czasu pracy do minimum.

Klasyfikując subotniki jako „pędy komunizmu”, Lenin zaciera jak gdyby różnicę między heroistyczną moralnością uczestnika/czki subotnika a moralnością człowieka komunistycznego, którą można by określić mianem nieheroicznego altruizmu (kolektywizmu). Moralność (światopogląd) człowieka komunistycznego - takiego, jakiego zakłada wizja z Państwa a rewolucji - dyscyplinuje go do pracy na rzecz ludzi „dalekich”, jednakże nie powinno tu być mowy o żadnym heroizmie, skoro komunistyczna praca staje się w komunizmie nie tylko formą zaspokajania potrzeby działania na rzecz dobra ogółu, ale zarazem - powszechnie przyswojonym - nawykiem, a przy okazji forma zaspokajania naturalnej potrzeby aktywności fizyczno-intelektualnej. Praca w komunizmie - jakkolwiek niekoniecznie atrakcyjna - uwolniona zostaje od momentów szczególnie uciążliwych. Tymczasem w przypadku uczestnika/czki subotników zaspokajanie potrzeby działania na rzecz dobra ogółu wiąże się z dramatycznymi wyborami moralnymi, walkami wewnętrznymi i niewątpliwie licznymi przykrościami związanymi z sama „materia” (nie uwolnionej jeszcze od momentów uciążliwych) pracy. Przedstawiając subotniki jako wzorzec przyszłej pracy komunistycznej, Lenin sugeruje mimochodem, iż istotnym elementem komunizmu będzie powszechny heroizm - wbrew występującej w pracy Państwo a rewolucja tendencji do podkreślania latwości życia komunistycznego. Niemniej jednak nie sposób przypisywać Leninowi koncepcji heroizmu dla heroizmu, koncepcji czyniącej heroizm wartością samoistna. Leninowska pochwała działań heroicznych (sugerująca ich ścisły związek z komunistycznym kolektywizmem) odnosi się w istocie do konkretnych - niezwykle brutalnych - realiów radzieckiego okresu przejściowego, w których od ludzkiej ofiarności zależało samo „być albo nie być” władzy radzieckiej, budującej socjalizm. Generalnie chodzi 
jednak o jak najszybszą eliminację potrzeby działań heroicznych, zapewnienie ludziom wygodnych warunków życia, bezkonfliktowych, harmonijnych stosunków społecznych i ogólne złagodzenie obyczajów. W tym ogólnym dążeniu mieści się również zamiar skrócenia czasu pracy.

Praca komunistyczna - jak już podkreśliliśmy - nie jest w ujęciu Lenina formą twórczej eksterioryzacji, satysfakcjonującą ze względu na samą swoją atrakcyjną „materię”, ale przede wszystkim formą służby społecznej (w komunizmie, jak zakładamy: relatywnie nieuciażliwej). O tyle też może Lenin postulować faktyczne zwiększenie stopnia alienacji pracy - gwoli maksymalnego skrócenia czasu jej trwania. Temu właśnie celowi służyć ma wprowadzenie systemu taylorowskiego. W niepublikowanym za życia Lenina pierwotnym szkicu Najbliżşych zadań władsy radzieckiej (1918 r.) czytamy:

Minusem systemu Taylora było to, że stosowano go w warunkach niewolnictwa kapitalistycznego i że służył on za środek do wyciskania z robotnika podwójnej czy potrójnej ilości pracy za poprzednią płacę, absolutnie nie licząc się z tym, czy robotnik najemny jest w stanie bez szkody dla organizmu ludzkiego dać z siebie owa podwójną czy też potrójną ilość pracy w ciagu tej samej liczby godzin. [...] musimy w całej Rosji wprowadzić system Taylora i amerykański naukowy sposób podnoszenia wydajności pracy, łącząc ten system ze skróceniem czasu pracy, z wykorzystywaniem nowych metod produkcji i organizacji pracy bez żadnej szkody dla siły roboczej pracującej ludności. Wprost przeciwnie, zastosowanie systemu Taylora - jeśli będą nim kierować sami ludzie pracy i jeśli będą oni dostatecznie świadomi - stanie się niezawodnym środkiem do dalszego, i to znacznego skrócenia obowiązującego dnia pracy dla całej ludności pracującej... (Lenin 1988e, 133).

W artykule Lenina z 1914 roku czytamy z kolei:

System Taylora - bez wiedzy i wbrew woli jego autorów - przygotowuje czasy, w których proletariat weźmie w swe ręce całą produkcję społeczną i powoła swoje, robotnicze komisje do prawidłowego podziału i uporządkowania całej pracy społecznej. Wielka produkcja, maszyny, koleje, telefon - wszystko to daje tysiące możliwości czterokrotnego skrócenia czasu roboczego zorganizowanych robotników, zapewniając im czterokrotnie lepsze warunki bytu niż obecnie (Lenin 1987, 357-358).

Czterokrotne skrócenie czasu pracy oznaczałoby - jak zauważa Stanisław Strumilin - „normę pracy w komunizmie nie wyższą od trzech godzin dziennie” (Strumilin 1962, 443). 
Wynikałoby stąd, iż przyszli ludzie komunistyczni żyć będą przede wszystkim w królestwie czasu wolnego. Przy tym założeniu - niezależnie od tego, czy potraktujemy przyszła pracę komunistyczną jako atrakcyjne pole ludzkiej samorealizacji i eksterioryzacji, czy też ujmować ją będziemy w kategoriach służby na rzecz wspólnoty - głęboko zakorzeniona w marksizmie koncepcja komunizmu, ukazująca ten ustrój przede wszystkim w świetle „komunistycznego stosunku do pracy” (który może być z kolei ujmowany bądź jako stosunek „potwierdzania się" twórcy/czyni w swych dziełach, bądź jako stosunek dobrowolnej, nie wymuszanej żadnymi zewnętrznymi „bodźcami” służby jednostki na rzecz wspólnoty), jest koncepcja dalece niepełna, nie rozstrzygająca, na czym polegać będzie w gruncie rzeczy życie ludzi komunistycznych. Wypowiedzi Lenina dotyczące pracy komunistycznej, implikujące bezwiednie obraz przyszłego społeczeństwa komunistycznego jako społeczeństwa ludzi zajętych głównie dobrowolną, bezpłatną pracą dla ludzi „dalekich”, uzasadnia jedynie doraźna potrzeba dowartościowania ofiarności uczestników/czek subotników (przez określanie ich mianem subotników „komunistycznych”). (Należy ponadto stwierdzić, iż przedmiotem tekstów Lenina o subotnikach nie jest komunizm jako taki, ale właśnie subotniki, a więc - ogólniej rzecz ujmując - zagadnienie pracy dobrowolnej).

W powyższych rozważaniach nad Leninowską koncepcją pracy komunistycznej akcentowaliśmy m.in. brak - w wypowiedziach Lenina - wątków pokrewnych koncepcji (przyszłej) pracy jako twórczej eksterioryzacji i samorealizacji, a więc koncepcji zakorzenionej w antropologii filozoficznej Marksa (która marksistom/kom pokolenia Lenina była zasadniczo nieznana). Warto podkreślić, iż w wypowiedziach Lenina na temat przyszłej pracy nie znajdujemy również wątków zbieżnych z koncepcją Frédérica Lordona, autora usiłującego łączyć Marksa ze Spinozą, proponującego zastąpienie klasycznej, Marksowskiej teorii wyzysku, a więc teorii wartości dodatkowej, teorią wyzysku uczuciowego, nawiązująca do Spinozjańskiej teorii afektów, a zarazem wypowiadającego się również na temat komunizmu: „Spinoza daje nam prawdziwą definicję komunizmu [...]: wyzysk uczuciowy skończy się wtedy, gdy ludzie będą umieli kierować swoje wspólne pragnienia [...] na przedmioty, które nie moga już ulegać przechwytywaniu..." (Lordon 2012, 218-219). Lordon obawia się, że (hipotetyczne) wyjście z kapitalizmu zaowocuje transformacją „monetarnej ekonomii radości” w „niepieniężną ekonomię uznania”, zachowującą ogólny mechanizm przechwytywania radości (,w każdym przypadku chodzi o to, by dodać inne moce do swojej własnej i w ten sposób zwiększyć wyprodukowany efekt, a towarzysząca temu radosna korzyść zewnętrzna podlega przechwyceniu" [Lordon 2012, 217]). Owej ekonomii radości płynącej z zewnątrz (kontemplacja siebie jako powodu radości dla innych), mającej charakter różnicujący i konkurencyjny, przeciwstawia Lordon 
„(niekapitalistyczna) ekonomię radości płynącej z wewnątrz, która polega na rozkoszowaniu się bez współzawodnictwa wspólnie wyprodukowanym celem” (Lordon 2012, 216). Odnosząc się do proponowanych przez Lordona konstrukcji pojęciowych, możemy stwierdzić, iż Lenin ani nie piętnuje (rywalizacyjnej) ekonomii uznania, ani też nie przewiduje (nierywalizacyjnej) ekonomii radości płynącej z wewnątrz. Problematyka (dystrybucji) radości (wytwarzanej w procesie pracy), podobnie jak problematyka eksterioryzacji (i zwiazzanych z nią satysfakcji/profitów), należy, jak sądzę, do bardziej szczegółowego poziomu analizy Lenin poprzestaje natomiast na szczeblu ogólniejszym, a więc na szczeblu opozycji dyscyplina (zewnętrzna) vs samodyscyplina. Na tym ogólnym szczeblu rozważań pojęciem definiującym pracę komunistyczną jest „dobrowolność”, niepodlegająca już dalszej problematyzacji. Leninowska koncepcja pracy komunistycznej, wolna od uwikłań w - kontrowersyjną na gruncie samego marksizmu - antropologię filozoficzną Marksa, nie wkracza więc również na obszar Spinozjańskiej antropologii afektów. Ujmowanie przyszłej pracy w kategoriach samodyscypliny nasuwa raczej skojarzenia z etyka Kanta, aczkolwiek Leninowi nie jest właściwa (kantowska) tendencja do podkreślania dramatyzmu opozycji skłonności vs obowiązek (a jeżeli już to jedynie w odniesieniu do okresu przejściowego, a nie do komunizmu). Lenin, nie obiecując radości, nie straszy nas też przyszłymi cierpieniami.

\section{Samodyscyplina negatywna}

Zajmiemy się teraz zagadnieniem samodyscypliny negatywnej. Do tej pory rozpatrywaliśmy człowieka komunistycznego jako człowieka samodyscyplinującego się do pracy, a więc jako człowieka nie wymagającego ekonomicznego pobudzania, motywowania, premiowania, rozliczania itd. W tej części komunistyczny człowiek samodyscyplinujący się interesuje nas jako człowiek samodzielnie powstrzymujący się od „ekscesów”, a więc człowiek niewymagający jakiegokolwiek nadzoru, człowiek zdolny do życia w wolności.

Zacznijmy od komentarza dotyczącego Leninowskiego ujęcia relacji między wolnością i demokracją. Państwo a rewolucja, jako tekst dotyczący przede wszystkim zagadnień okresu przejściowego - wzywający do zburzenia burżuazyjnej machiny państwowej i zastąpienia jej nowym państwem, urzeczywistniającym ultrademokratyczną zasadę udziału całej ludności w wykonywaniu funkcji państwowych - poświęcony jest przede wszystkim demokracji. Lenin nadaje tu absolutnie pryncypialne znaczenie Marksowskim (pochwalnym) uwagom dotyczącym demokratycznych rozwiązań Komuny Paryskiej, mających (zdaniem Lenina) 
stanowić wzór dla proletariackiego państwa w Rosji (Lenin 1951, 224)4 . Jednym słowem, demokracja (radykalna) jest tu dla Lenina kwestią podstawowa - przedmiotem fundamentalnego sporu z oportunizmem - tak Bernsteinowskim, jak i Kautskistowskim (Lenin 1951, 225) $)^{5}$. Na podstawie wielu wypowiedzi Lenina, zarówno z pracy Państwo a rewolucja, jak i innych tekstów, moglibyśmy wysunąć tezę, iż Lenin jest raczej demokratą niż wolnościowcem. W świetle tezy sformułowanej w niepublikowanym za życia Lenina wariancie Najbliżşych zadań władsy radzieckiej czas wolny, wygospodarowany dzięki wprowadzeniu tayloryzmu, zostanie przeznaczony na demokrację: „każdy dorosły obywatel poświęca codziennie sześć godzin na pracę fizyczną i cztery godziny na pracę w dziedzinie rządzenia państwem" (Lenin 1988e, 133-134).

Byłaby to jednak teza błędna. Lenin jest w istocie raczej wolnościowcem niż demokrata. Albo inaczej: demokracja jest (w ujęciu Lenina) jedynie środkiem i to środkiem przejściowym ${ }^{6}-$ do celu, jakim jest wolność. Od ustroju opartego na konsekwentnie demokratycznym zarządzaniu (socjalizm) Lenin wyżej ceni ustrój, w którym zanika potrzeba jakiegokolwiek zarządzania (komunizm). Prymat wolności nad demokracja jest założeniem Leninowskiej koncepcji obumierania państwa, będącego zarazem jak uporczywie podkreśla Lenin (za Engelsem ${ }^{7}$ ) - procesem obumierania demokracji ${ }^{8}$. Zarządzanie (demokratyczne) zastapione zostanie obyczajową regulacja życia społecznego:

4 „Robotnicy zdobywszy władzę polityczną zdruzgocą dawny aparat biurokratyczny, zburzą go do podstaw, kamienia na kamieniu zeń nie zostawią, zastapią go nowym, złożonym z tych samych robotników i pracowników i præecin przeistaczaniu się ich w biurokratów zastosowane zostaną niezwłocznie środki szczegółowo omówione przez Marksa i Engelsa: 1) nie tylko obieralność, ale i usuwalność w każdej chwili; 2) płaca nie przewyższająca płacy robotnika; 3) natychmiastowe przejście do tego, aby wsayscy pełnili czynności kontroli i nadzoru, aby wszyscy na pewien czas stawali się »biurokratami« i aby wskutek tego niket nie mógł stać się »biurokratą «" (Lenin 1951, 224).

5 „Kautsky zupełnie nie pojął różnicy pomiędzy parlamentaryzmem burżuazyjnym, będącym połączeniem demokracji (nie dla ludu) z biurokracją (przecin ludowi), a proletariackim demokratyzmem, który niezwłocznie zastosuje posunięcia podcinające biurokratyzm u podstaw i który będzie w stanie doprowadzić te posunięcia do końca, do zupełnego unicestwienia biurokratyzmu, do całkowitego urzeczywistnienia demokracji dla ludu. // Kautsky ujawnił tu wciąż tę samą "zabobonną cześć« dla państwa, "zabobonną wiarę« w biurokratyzm” (Lenin 1951, 225).

6 , ,...] demokracja bynajmniej nie jest kresem, poza którym dalszej drogi nie ma, lecz tylko jednym z etapów na drodze od feudalizmu do kapitalizmu i od kapitalizmu do komunizmu" (Lenin 1951, 216).

7 ,[...] ów wyraz [socjaldemokracja - przyp. FN] może chyba ujść, mimo że nie jest najlepszą nazwą dla partii, której program ma nie tylko ogólnosocjalistyczny charakter, lecz wręcz komunistyczny, i której ostatecznym celem politycznym jest przezwyciężenie państwa w jego całokształcie, a więc równiė̇ i demokracji” (Engels 1971, 502).

8, „...] zapomina się stale, że zniesienie państwa jest zniesieniem również demokracji, że obumieranie państwa jest obumieraniem demokracji. // [...] Demokracja nie jest identyczna z podporządkowaniem się mniejszości - większości. Demokracja jest to państwo uznające, że mniejszość powinna się podporządkować większości, tj. organizacja dla stosowania systematycznej przemocy jednej klasy nad drugą, jednej części ludności nad druga" (Lenin 1951, 202). 
przestrzeganie elementarnych norm zgodnego współżycia społecznego stanie się powszechnym zwyczajem.

Lenin utożsamia wolność z brakiem państwa (choćby demokratycznego), co zbliża go do anarchizmu: „Dopóki istnieje państwo - nie ma wolności. Kiedy będzie wolność, nie będzie państwa” (Lenin 1951, 213).

Dopiero w społeczeństwie komunistycznym, kiedy opór kapitalistów jest już ostatecznie złamany, kiedy kapitaliści zniknęli, kiedy nie ma klas (tj. nie ma różnic pomiędzy członkami społeczeństwa pod względem ich stosunku do społecznych środków produkcji), dopiero wówczas „państwo przestaje istnieć i možna mówić o wolności” (Lenin $1951,208)^{9}$.

Dla nas celem ostatecznym jest zniesienie państwa, tj. wszelkiej zorganizowanej i systematycznej przemocy, wszelkiej w ogóle przemocy nad ludźmi. Nie oczekujemy nadejścia takiego ładu społecznego, w którym by nie była przestrzegana zasada, że mniejszość podporządkowuje się większości. Ale dążąc do socjalizmu jesteśmy przekonani, że będzie on przerastał w komunizm, a w związku z tym zanikać będzie wszelka potrzeba przemocy nad ludźmi w ogóle, potrzeba podlegania jednego człowieka drugiemu, jednej części ludności - drugiej, ponieważ ludzie prayzznyczaja sie do przestrzegania elementarnych warunków życia społecznego bez przemocy i bez podlegania (Lenin 1951, 202-203).

Demokracja jest - jak już wspomnieliśmy - tylko szczeblem przejściowym na drodze do wolnego ustroju bezpaństwowego (zakładającego obumarcie demokracji). Początkiem procesu obumierania demokracji jest moment urzeczywistnienia demokracji zupełnej. Jednym słowem: by demokracja mogła ustapić miejsca wolności, musi zostać najpierw w pełni urzeczywistniona.

Dopiero wtedy [w społeczeństwie komunistycznym - przyp. FN] możliwa będzie i urzeczywistniona zostanie demokracja istotnie zupełna, istotnie bez żadnych wyłączeń. I wtedy dopiero demokracja zacznie obumierać w następstwie tej prostej okoliczności, że ludzie oswobodzeni od kapitalistycznej niewoli, od niezliczonych okropności, potworności, niedorzeczności, nikczemności wyzysku kapitalistycznego

9 Lenin nawiązuje tu do krytycznej uwagi Engelsa o postulacie „wolnego państwa ludowego”: „[...] mówienie o wolnym państwie ludowym jest zupełną bzdura. Dopóki proletariat postuguje sie jeszcze państwem, posługuje się nim nie w interesie wolności, lecz po to, by trzymać w karbach swych przeciwników, z chwilą zaś kiedy może być mowa o wolności, państwo jako takie przestaje istnieć" (Engels 1972b, 7). 
praymykna stopniowo do przestrzegania elementarnych, od wieków znanych, w ciagu tysiącleci we wszystkich przepisach powtarzanych reguł współżycia, przestrzegania ich bez przemocy, bez przymusu, bez podlegania, bez specjalnego aparatu do przymuszania, który nazywa się państwem (Lenin 1951, 208).

Powyższa wypowiedź pomija jednak niezwykle istotne szczegóły. Dlaczego narodziny wolności (a więc śmierć demokracji) wymagaja urzeczywistnienia demokracji zupełnej? Odpowiedź Lenina jest niezwykle konsekwentna. Urzeczywistnienie demokracji zupełnej oznacza włączenie całej ludności do udziału w „zarządzaniu”. Kiedy zaś cała ludność uczestniczyć będzie w „zarządzaniu”, a więc również kontrolowaniu, kontrola nad ludźmi stanie się wszechogarniająca - nie będzie się można od niej uchylić. Niemożność naruszania obowiązujących norm - wskutek powszechności kontroli - sprawi, iż ludzie przyzwyczają się do przestrzegania owych norm nawet bez jakiejkolwiek kontroli. I właśnie wtedy kontrola, zarządzanie, demokracja, państwo, staną się niepotrzebne. Przytoczmy dłuższy ustęp z Państwa a rewolucji, przedstawiający powyższe rozumowanie:

Od chwili kiedy wszyscy członkowie społeczeństwa, albo przynajmniej ogromna ich większość, nauczyli się sami zarządzać państwem, sami sprawę tę wzięli w swoje ręce, „zorganizowali” kontrolę nad znikomą mniejszością kapitalistów, nad pankami pragnącymi zachować narowy kapitalistyczne, nad tymi robotnikami, których kapitalizm głęboko zdeprawował - od tej chwili zaczyna znikać potrzeba jakiegokolwiek zarządzania w ogóle. Im zupełniejsza jest demokracja, tym bliższa jest chwila, kiedy staje się ona zbyteczna. Im bardziej demokratyczne jest „państwo” składające się z uzbrojonych robotników i „nie będące już państwem we właściwym znaczeniu tego słowa”, tym szybciej zaczyna obumierać wsz̨elkie państwo.

Kiedy bowiem wsajyscy nauczą się zarządzać i będą rzeczywiście samodzielnie zarządzać produkcją społeczną, samodzielnie prowadzić ewidencję i wykonywać kontrolę nad darmozjadami, paniczykami, oszustami i podobnymi im „stróżami tradycji kapitalizmu" - wówczas uchylanie się od tej ogólnoludowej ewidencji i kontroli stanie się siłą rzeczy tak niesłychanie trudne, tak bardzo rzadkim będzie wyjątkiem, pociagać będzie prawdopodobnie tak szybką i poważną karę (bo uzbrojeni robotnicy to ludzie praktycznego życia, a nie sentymentalne inteligenciki, i z pewnością nie pozwolą kpić z siebie), że konieczność przestrzegania nieskomplikowanych, zasadniczych norm wszelkiego współżycia ludzkiego bardzo prędko stanie się prayyzayyczajeniem. 
I wtedy otwarte zostaną na oścież wrota prowadzące od pierwszej fazy społeczeństwa komunistycznego do jego fazy wyższej, a wraz z tym do zupełnego obumierania państwa (Lenin 1951, 218-219).

Droga do wolności wiedzie zatem przez system demokratycznej niewoli. Demokracja zazwyczaj łączona z wolnością - okazuje się (jako system wszechogarniającej kontroli całej ludności przez całą ludność) przeciwieństwem wolności, ale zarazem nieodzownym narzędziem tresury, mającej na celu stworzenie ludzi zdolnych do życia w wolności. Tę dość brutalną wizję wolnościowej tresury łagodzi założenie, iż obumieranie ekscesów warunkujące obumieranie demokratycznego państwa - będzie rezultatem nie tylko tresury, ale również sprzyjających warunków społecznych:

Wreszcie jedynie komunizm stwarza warunki, w których państwo staje się zupełnie zbędne, gdyż nie ma kogo dławić - „nie ma kogo” w sensie klasy, w sensie systematycznej walki z określonym odłamem ludności. Nie jesteśmy utopistami i bynajmniej nie negujemy możliwości i nieuchronności ekscesów posžžgólnych jednostek jak również konieczności tłumienia takich ekscesów. Ale, po pierwsze, do tego nie jest potrzebna specjalna machina, specjalny aparat dławienia, czynić to będzie sam uzbrojony lud z taka samą prostotą i łatwością, z jaką każde skupisko ludzi cywilizowanych, nawet w dzisiejszym społeczeństwie, rozłącza uczestników bójki lub nie dopuszcza do przemocy nad kobieta. Po wtóre, wiemy, że podstawową przyczyną społeczna ekscesów polegających na naruszaniu zasad współżycia jest wyzysk mas, ich ubóstwo i nędza. Wraz z usunięciem tej głównej przyczyny ekscesy siłą rzeczy zaczną ,obumierać”. Nie wiemy, jak szybko i w jakiej kolejności, ale wiemy, że będą obumierać. Z ich obumieraniem nastąpi także obumieranie państwa (Lenin 1951, 209).

Zanik potrzeby dławienia będzie więc także rezultatem zaniku zjawisk społecznych wywołujących oburzenie, protest i bunt, skoro:

Wyrażenie „państwo obumiera” wybrane jest nader trafnie, bo wskazuje zarówno na stopniowość procesu, jak i na jego żywiołowość. Jedynie przyzwyczajenie może oddziałać i niewatpliwie oddziała w taki sposób, gdyż wokół siebie obserwujemy miliony razy, jak łatwo ludzie przyzwyczajaja się do przestrzegania niezbędnych dla nich reguł współżycia, o ile nie ma wyzysku, o ile nie ma nic takiego, co wzbudza oburzenie, wywołuje protest i bunt, stwarza niezbędność dławienia (Lenin 1951, 208). 
W tym miejscu wypada się odnieść do całkowicie błędnej interpretacji Leninowskiej koncepcji wolności, przedstawionej w książce Andrzeja Walickiego Marksižm i skok do królestwa wolności. Drieje komunistycznej utopii. Walicki ukazuje Lenina jako przywódcę owładniętego fanatycznym pragnieniem urzeczywistnienia - w najszybszym możliwym terminie - Marksowskiej utopii „skoku do królestwa wolności”, mając przy tym na względzie nie to „królestwo wolności”, o którym pisze Marks w trzecim tomie Kapitału, ale to, o którym pisze Engels w Anty-Dühringu („,skok do królestwa wolności” jest tu ujęty jako ustanowienie panowania ludzkości nad przyrodą i historią [Engels 1972a, 316]). Cały przedNEPowski okres władzy radzieckiej ma być - zdaniem Walickiego - okresem, w którym Lenin, wbrew okolicznościom, nie biorąc pod uwagę jakichkolwiek racji pragmatycznych, realizuje utopijny plan bezpośredniego przejścia do komunizmu, plan natychmiastowej realizacji Marksowskiego „celu ostatecznego”. Lenin - w teorii i praktyce - przeprowadza „systematyczny, brutalny atak na rynek w imię komunistycznego ideału gospodarki bezrynkowej [...]”. Nie jest to „postępowanie wymuszone przez okoliczności zewnętrzne, ale opcja ideologiczna, „świadome dążenie do urzeczywistnienia utopii Marksa” (Walicki 1996, 344). W całym okresie 1918-1921, jak stwierdza Walicki,

\begin{abstract}
partia Lenina walczyła o „bezpośrednie przejście” do komunizmu, [...] był to wynik opcji ideologicznej mocno uzasadnionej doktrynalnie, [...] pociagnęło to za sobą próby organizowania życia społecznego na wzór koszarowy [...] brutalizacja tych metod [...] nie da się wytłumaczyć jedynie okolicznościami zewnętrznymi. Na okoliczności takie można było przecież reagować również ustępstwami, ale tego właśnie zabraniała wówczas fanatyczna wiara w utopię (Walicki 1996, 347).
\end{abstract}

Jest to interpretacja podwójnie nieprawdziwa. Po pierwsze, nie jest prawdą, iż Lenin dąży w okresie „komunizmu wojennego” do realizacji tak czy inaczej rozumianego „celu ostatecznego”. Lenin, który bardzo wyraźnie odróżnia komunizm, „cel ostateczny” (ustrój bezpaństwowy, realizujący zasadę podziału wedle potrzeb) od socjalizmu (czy ogólnie: społeczeństwa przejściowego), dąży w tym okresie - nie wbrew okolicznościom, ale właśnie sprowokowany rozpaczliwymi okolicznościami nadciągającej katastrofy humanitarnej do przezwyciężenia kryzysu aprowizacyjnego i uratowania proletariatu przed biologiczną zagłada metodami „wojennymi”, „szturmowymi”, implikującymi zarazem przyśpieszone (w stosunku do wyjściowego planu) przechodzenie do socjalizmu - nie komunizmu, ale właśnie socjalizmu, a o ile sam mówi w tym kontekście o komunizmie, to nie ma 
na względzie komunizmu w znaczeniu naukowym, ale komunizm w znaczeniu potocznym, które nie odróżnia komunizmu od socjalizmu i sprowadza komunizm do wspólnej własności (trzymając się potocznego znaczenia terminu „komunizm”, możemy rzeczywiście uznawać, iż przeprowadzona przez bolszewików nacjonalizacja była „bezpośrednim przejściem” do komunizmu). Po drugie, sam „cel ostateczny”, mający jakoby przyświecać Leninowi, definiowany jest przez Walickiego w sposób najzupełniej absurdalny. Owym „celem ostatecznym" ma być bowiem wolność, utożsamiona po prostu z gospodarką bezrynkowa, zakładająca przekształcenie całego społeczeństwa w jedną wielka „fabrykę” pracująca wedle jednego, z góry ustanowionego planu (czyli „królestwo wolności z Anty-Dühringa).

\begin{abstract}
Lenin nie był subtelnym filozofem wolności. Mimo to jednak cała jego działalność rewolucyjna skierowana była ku urzeczywistnieniu komunistycznej wizji wyzwolenia wyzwolenia od ślepych konieczności życia ekonomicznego i społecznego. Wolność polegała według tej wizji na zdolności podporządkowania żywiołowych sił ścisłej, świadomej kontroli i osiagnięciu w ten sposób suwerennego panowania nad zbiorowym losem (Walicki 1996, 267).
\end{abstract}

W interpretacji Walickiego, trzymającego się ściśle Engelsowskiej metafory „skoku do królestwa wolności”, likwidacja rynku (opanowanie żywiołowych sił ekonomicznych) urasta niejako do rangi samoistnego celu marksizmu, jego „celu ostatecznego”. W istocie jednak, tak dla Marksa i Engelsa, jak i dla Lenina, bezrynkowa gospodarka planowa (wolność w królestwie konieczności) nie jest celem samym w sobie, a jedynie środkiem, przesłanką urzeczywistnienia komunistycznego ideału społeczeństwa i człowieka. Nie jest łatwo w sposób jednoznaczny określić - „w imieniu” marksizmu - na czym ten ideał polega i na jakiej aksjologii się wspiera. Możliwe są różne interpretacje. Jedna z nich głosi, iż owa wolność w królestwie konieczności (z Engelsowskiego Anty-Dübringa) jest po prostu środkiem urzeczywistnienia „prawdziwego królestwa wolności” z trzeciego tomu Kapitału. Do takiej właśnie interpretacji zbliża się również Walicki, gdy komentuje wypowiedź Marksa o „prawdziwym królestwie wolności” (Walicki 1996, 91) a także gdy omawia poglądy Trockiego (Walicki 1996, 367). Niestety Walicki nie czyni z tej interpretacji żadnego użytku w swej zasadniczej narracji o Leninie i bezustannie powtarza tezę o Leninowskim fanatyzmie w dążeniu do natychmiastowej realizacji „ideału” gospodarki bezrynkowej, wychodząc z założenia, że jedynym wyjaśnieniem towarzyszącego „komunizmowi wojennemu” (i udzielającego się również Leninowi) rewolucyjnego entuzjazmu jest okoliczność, 
iż w okresie tym zmierzano do realizacji „celu ostatecznego”. Nie trzeba chyba dowodzić, że model gospodarki bezrynkowej realizowany w okresie 1918-1921 ma niewiele wspólnego z Leninowskim ideałem „celu ostatecznego” (a także istotnie odbiega od Leninowskiego modelu socjalistycznego ustroju przejściowego, zaprojektowanego na znacznie spokojniejsze czasy). Bojowe, szturmowe, rewolucyjne metody walki z rynkiem - i towarzyszący im „entuzjazm” - nie pozostaja w żadnym związku z Leninowską aksjologia, co więcej, przekreślają realizację ważnych dla Lenina celów „etapowych” (jak chociażby plan oderwania chłopa średniaka od kułaka i skłonienia go do sojuszu z biedniakiem i władzą radziecka). Kompletnym nieporozumieniem jest interpretowanie rozwiązań proponowanych przez Lenina w odniesieniu do fazy dyktatury proletariatu i socjalizmu jako wyrażających Leninowską koncepcję wolności.

Jak jednak - pyta Walicki - połączyć można „całkowitą wolność” z najściślejsza dyscypliną i kontrola - kontrolą obejmująca wszystkie sfery życia, od produkcji do konsumpcji włącznie? Lenin nie widział w tym sprzeczności, chodziło mu bowiem o wolność zbiorowa, wolność klasy, a nie wolność indywidualnych robotników; o wolność jako racjonalną kontrolę zbiorowego losu, a nie o swobodę realizowania celów partykularnych; o wolność jako świadomą realizację wspólnego celu klasowego, a nie o wolność jako chaotyczny pluralizm i „nieświadomą” spontaniczność działań. Wyraźnie odróżniał społeczną emancypację klasy robotniczej od wolności robotników jako jednostek lub jako członków partykularnych grup interesu. Wyzwolona od kapitalizmu klasa robotnicza miała „zdruzgotać” swych wrogów klasowych i zastąpić niewolę kapitalistyczną dobrowolną subordynacją i samodyscypliną. Robotnicy mieli być wolni nie od kontroli i nadzoru jako takich, lecz od burizasyjnej kontroli i nadzoru. Jako obywatele mieli być wolni od władzy burżuazyjnej, ale podporządkowani swej własnej dyktaturze klasowej... (Walicki 1996, 320).

Powyższy fragment sugeruje, iż Leninowska koncepcja „całkowitej wolności” sprowadza się do Engelsowskiej koncepcji „skoku”, a ponieważ ta ostatnia odnosi się do wolności „gatunkowej”, zbiorowej (panowanie ludzkości nad przyrodą i historia), w koncepcji Lenina nie ma miejsca na wolność indywidualna; że, innymi słowy, zdaniem Lenina nie ma żadnej sprzeczności między wolnością i najściślejszą kontrolą. Jest to całkowity absurd. Owszem, Lenin posługuje się terminem wolność w różnych znaczeniach, także w takim, które odpowiadałoby zbiorowej wolności racjonalnego kształtowania życia społecznego. Należy jednak wyraźnie odróżniać rozmaite wolności ujmowane przez Lenina jako zdobycze okresu przejściowego od Leninowskiego ideału wolności komunistycznej. Lenin bardzo wyraźnie 
stwierdza, iż komunistyczna wolność zakłada... brak państwa (choćby ultrademokratycznego, którego funkcje wypełnia cała bez wyjątku ludność), a więc brak jakiejkolwiek kontroli nad jednostkami - zakłada więc (jako antropologiczna przesłankę) zdolność jednostek ludzkich do harmonijnego współżycia bez jakiegokolwiek (choćby najdemokratyczniejszego i sprawowanego przez całą ludność) nadzoru. Leninowski ideał wolności zakłada więc nie tylko brak dyktatury pewnej części społeczeństwa nad inną jego częścią, ale również brak neutralnego klasowo - zarządzania. Im mniej zarządzania, tym więcej wolności. Społeczeństwo dyscypliny fabrycznej, społeczeństwo jako jedna wielka fabryka, będąca zarazem jednym wielkim biurem, ewidencjonującym i kontrolującym - Lenin wyraźnie to stwierdza - nie jest „naszym ideałem”, a jedynie koniecznym szczeblem przejściowym. Jest to ideał okresu przejściowego, w którym nie może być jeszcze mowy o wolności komunistycznej - może być natomiast mowa o najbardziej radykalnej demokracji. Leninowska wolność, możliwa jedynie w komunizmie, ma być, wbrew temu, co sugeruje Walicki, wolnością indywidualna, co więcej, ma to być - opiewana przez liberalizm - wolność negatywna, „wolność od”, mianowicie wolność każdej jednostki od jakichkolwiek (choćby najłagodniejszych i najbardziej wyrafinowanych) form przymusu zewnętrznego. Więcej jeszcze: o ile Marksowi przypisać możemy wiarę w to, iż owa wolność negatywna stanowić będzie jedynie korelat wolności pozytywnej, wolności do rozwijania przez każdą jednostkę swych „sił ludzkich”, wolności do „piekielnego trudu” ludzkiego samourzeczywistniania się, o tyle u Lenina nie znajdujemy żadnych sugestii odnośnie do tego, jaki (pozytywny) użytek ze swej wolności negatywnej powinna czynić jednostka w przyszłym społeczeństwie komunistycznym. To, co z perspektywy autora niniejszych słów jest raczej brakiem, luką koncepcji Leninowskiej, z perspektywy Walickiego, głoszącego apologię liberalnej wolności negatywnej, powinno stanowić akurat zasługę.

Przyjrzyjmy się jeszcze jednej wypowiedzi Walickiego:

Tak więc „żelazna dyscyplina” w punkcie wyjścia, plus przeszkolenie całej ludności w wielkoprzemysłowej pracy produkcyjnej pod nadzorem robotniczej awangardy, wytworzy przyzwyczajenie do spełniania odpowiednich funkcji bez przymusu i zewnętrznego nadzoru. Tym sposobem zniknie problem scentralizowanej kontroli i nadzoru nad praca. Robotnicy uwolnią się od zewnętrznego przymusu, ponieważ przekształcą się w doskonałe roboty, wykonujące swą pracę, zredukowana do najprostszych czynności, w sposób automatyczny (Walicki 1996, 326). 
Tak jak w wypowiedzi poprzednio cytowanej Walicki pomylił Leninowski model socjalizmu z Leninowskim modelem komunizmu, utożsamiając Leninowski ideał wolności z „wolnością zbiorowa” („racjonalną kontrolą zbiorowego losu”), łączącą się (w socjalizmie) z najściślejszą dyscypliną i kontrolą (pomimo, iż Lenin explicite przedstawia własny ideał wolności komunistycznej jako przeciwieństwo socjalistycznej dyscypliny fabryczno-biurowej), tak tutaj Walicki miesza przyzwyczajenie całej ludności do wypełniania (upraszczających się) funkcji państwowych z przyzwyczajeniem całej ludności do harmonijnego współżycia i dobrowolnej pracy (czyli ze zdolnością do życia w społeczeństwie bezpaństwowym). O ile to pierwsze przyzwyczajenie stanowi warunek urzeczywistnienia socjalistycznego ideału „demokracji zupełnej”, o tyle to drugie stanowi przesłankę urzeczywistnienia komunistycznego ideału wolności indywidualnej. (Walicki miesza tu dodatkowo upraszczanie się funkcji państwowych z upraszczaniem się samej pracy). Niemniej jednak Walicki przyznaje tu, iż Leninowskim ideałem jest wolność od (wszelkiego) zewnętrznego przymusu i nadzoru (a nie „wolność zbiorowa" pod nadzorem proletariackiej dyktatury). Beneficjenci/tki tego rodzaju wolności wolności indywidualnej i negatywnej - okazuja się jednak... „robotami”. Walicki dziwi się następnie, jak ta „ponura utopia” społeczeństwa robotów mogła wydawać się atrakcyjna „niektórym przedstawicielom marksistowskiego rewizjonizmu” (Walicki 1996, 326). Cóż jednak „robotycznego” i „ponurego” w dobrowolnym przestrzeganiu przez ludzi elementarnych norm harmonijnego współżycia i w dobrowolnej pracy dla społeczeństwa? Czyżby homo sapiens (w przeciwieństwie do „robota”) miał być ze swej natury istotą wymagająca zewnętrznego nadzoru i przymusu, i cała kwestia sprowadza się tylko do tego, czy będzie to nadzór nieskrępowany żadnymi prawami, czy też - jak proponuje Walicki nadzór oparty na pewnych stałych regułach (rządach prawa)? Rezultaty podjętej przez Walickiego krytyki Lenina wydają się paradoksalne. Liberał, obrońca wolności negatywnej, w celu zdezawuowania Leninowskiego ideału wolności od wszelkiego przymusu zewnętrznego, zmuszony jest głosić, przynajmniej implicite, iż człowiek nie jest istotą zdolną do życia w społeczeństwie bezpaństwowym (bez-prawnym), a więc w społeczeństwie konsekwentnie urzeczywistniającym ideał wolności negatywnej.

\section{Komunistyczna wszechstronność}

Ludzie komunistyczni będą, zdaniem Lenina, ludźmi wszechstronnie rozwiniętymi, umiejącymi robić „,wszystko”:

Kapitalizm nieuchronnie pozostawia socjalizmowi w spadku, z jednej strony, dawne, ukształtowane w ciagu stuleci różnice między robotnikami, związane z zawodem 
i rzemiosłem, z drugiej strony - związki zawodowe, które tylko bardzo powoli, w ciagu wielu lat, mogą się rozwijać i będa się rozwijały w szersze, mniej cechowe zwiazki produkcyjne (obejmujące całe gałęzie produkcji, a nie tylko cechy, rzemiosła i zawody), następnie zaś, poprzez te związki produkcyjne, będa przechodziły do zniesienia podziału pracy między ludźmi, do wychowywania, nauczania i przygotowywania wszechstronnie rozwinietych i wszechstronnie przygotowanych ludzi, ludzi, którzy umieja robic wszystko. Ku temu komunizm idzie, musi iść i dojdrie, lecz dopiero po wielu latach (Lenin 1988a, 32-33).

Głosząc - w odniesieniu do komunizmu - ideał człowieka wszechstronnego, Lenin powtarza oczywiście idee Marksa, i tak jak w przypadku Marksowskiej, postulowana przez Lenina wszechstronność ma dwa wymiary: wewnątrz-proletariacki i proletariacko-inteligencki. W pierwszym przypadku chodzi o zastapienie robotnika/cy „jednostronnego”, „,cząstkowego”, „monotechnicznego” robotnikiem/cą uniwersalnym/a, politechnicznym/a, czyli w gruncie rzeczy inżynierem/ką, znającym/ą naukowe podstawy wszystkich gałęzi produkcji i potrafiącym/a płynnie przechodzić z jednej dziedziny do drugiej. Stąd też w myśli pedagogicznej Lenina (i Krupskiej) tak wielką rolę odgrywa postulat kształcenia politechnicznego w powiązaniu z kształceniem ogólnym (dopiero na solidnej podbudowie wykształcenia politechnicznego i ogólnego powinno się prowadzić kształcenie monotechniczne, przysposabiające do pracy w konkretnych zawodach). Wymiar drugi to z kolei postulat zatarcia - uchwytnych socjologicznie - różnic między proletariatem a inteligencją (przy jednoczesnym zatarciu różnic między ludnością wiejską i miejska) - drogą równania w górę. Mówiąc w tym kontekście o równaniu w górę, mamy oczywiście na względzie podnoszenie poziomu kształcenia proletariatu do poziomu inteligencji (w zakresie ogólnego rozwoju umysłowego i wyrobienia kulturalnego), co jednak nie może oznaczać upodobnienia proletariatu do starej inteligencji społeczeństwa kapitalistycznego równie ,jednostronnej” jak kapitalistyczny proletariat. Drugą stroną medalu jest bowiem Marksowska - idea proletaryzacji inteligencji, włączenia całej ludności do udziału w produkcji materialnej. Idea zniesienia przeciwieństwa między pracą fizyczną i umysłową ma być - tak w ujęciu Marksa, jak i Lenina i Krupskiej - realizowana zarówno drogą intelektualizacji pracy fizycznej, jak i produkcyjnego (politechnicznego) wychowywania całej ludności. Lenin wzywając proletariat do odnoszenia się z należytym szacunkiem do ściśle inteligenckich kompetencji starej inteligencji burżuazyjnej (i nakazując młodzieży komunistycznej krytyczne 
przyswajanie sobie całego kulturalnego dorobku ludzkości) - surowo piętnował inteligencką niezdolność do działań kolektywnych, wymagających pewnej dyscypliny.

Dyscyplinę i organizację, do których z takim trudem wdraża się burżuazyjny inteligent, ze szczególną łatwością przyswaja sobie proletariat właśnie dzięki tej „szkole”, jaką jest dla niego fabryka (Lenin 1985, 355-356).

Nikt nie odważy się zaprzeczyć, że inteligencja, jako odrebna warstwa współczesnych społeczeństw kapitalistycznych, charakteryzuje się, ogólnie biorąc, właśnie indywidualizmem i niezdolnością do dyscypliny i organizacji (por. choćby znane artykuły Kautskiego o inteligencji); tym między innymi różni się na niekorzyść ta warstwa społeczna od proletariatu; tu kryje się jedna z przyczyn inteligenckiej mięczakowatości i chwiejności, która tak często daje się we znaki proletariatowi; ta właśnie cecha inteligencji jest nierozłącznie związana $\mathrm{z}$ codziennymi warunkami jej życia, z warunkami jej zarobkowania, zbliżonymi pod bardzo wieloma względami do warunków egaystencii drobnomieszrzaństwa (praca w pojedynkę lub w bardzo małych zespołach itd.) (Lenin 1985, 240-241).

Oto gdzie proletariusz, który przeszedł szkołę „fabryki”, może i powinien dać lekcję anarchistycznemu indywidualizmowi. Świadomy robotnik już dawno wyzwolił się z tych powijaków, kiedy to stronił od inteligenta jako takiego. Świadomy robotnik umie cenić ów bogatszy zasób wiedzy, ów szerszy widnokrąg polityczny, który znajduje u socjaldemokratów inteligentów. Ale w miarę jak kształtuje się u nas prawdžiwa partia, świadomy robotnik musi nauczyć się odróżniać psychologię bojownika armii proletariackiej od psychologii burżuazyjnego inteligenta popisującego się anarchistycznym frazesem, musi nauczyć się żadać, aby obowiązki członka partii spełniał nie tylko jej szeregowy członek, lecz także „ludzie z góry”... (Lenin 1985, 359).

W tym miejscu interesować nas będzie jednakże pierwsza strona medalu - wizja „inteligentyzacji” proletariatu (przy zachowaniu przez proletariat - wykształconej w fabryce zdolności do działań kolektywnych i zorganizowanych). Otóż w ścisłym związku z ową wizją należy rozpatrywać Leninowską koncepcję rewolucji kulturalnej. Trudności towarzyszące radzieckiemu budownictwu socjalistycznemu umacniały Lenina w przekonaniu, iż droga wiodącą społeczeństwo porewolucyjne ku socjalizmowi i komunizmowi jest droga gruntownej rewolucji kulturalnej (sam termin „,rewolucja kulturalna” pojawia się u Lenina 
dopiero w 1923 roku, w tekście O spótdzielczości $\left.i^{10}\right)$. Rewolucji tej miały przyświecać m.in. następujące cele:

- wyrównanie poziomów edukacyjnych (drogą równania w górę);

- przejęcie z rąk (a właściwie umysłów) starej inteligencji burżuazyjnej całego kulturalnego (w tym intelektualnego) dorobku ludzkości, by mógł on służyć całemu społeczeństwu i stanowić punkt wyjścia do rozwoju nowej kultury proletariackiej/socjalistycznej/komunistycznej (nowa kultura - w myśl poglądu Lenina, a wbrew poglądom głoszonym w kręgach Proletkultu - nie może być tworzona na spalonej ziemi, ale wyłącznie jako krytyczna kontynuacja kultury dotychczasowej);

- upowszechnianie nowoczesnej kultury pracy, odpowiadającej najnowocześniejszym trendom techniki światowej (w obrębie zelektryfikowanego przemysłu maszynowego);

- upowszechnianie nowej, egalitarnej, koleżeńskiej kultury współżycia międzyludzkiego w rodzinach, zespołach pracowniczych i wszelkiego rodzaju kolektywach.

Rewolucję kulturalną można rozpatrywać z dwóch odrębnych punktów widzenia. Po pierwsze jako rewolucję przygotowująca ludzi do życia w - nieistniejącym jeszcze społeczeństwie komunistycznym, a więc - przy założeniu, iż jakościowo nowy ustrój wymaga jakościowo nowych ludzi (ci zaś nie powstaja automatycznie pod wpływem obiektywnej dialektyki rozwoju sił wytwórczych i stosunków produkcji) - jako przedsięwzięcie mające na

10, „...] cały nasz pogląd na socjalizm uległ gruntownej zmianie. Ta gruntowna zmiana polega na tym, że główny nacisk kładliśmy i musieliśmy kłaść na walkę polityczną, rewolucję, zdobycie władzy itd. Obecnie zaś główny nacisk przenosi się gruntownie gdzie indziej - na pokojowa, organizacyjną 'kulturalną' pracę. Skłonny byłbym powiedzieć, że punktem ciężkości stają się dla nas sprawy krzewienia kultury, gdyby nie stosunki międzynarodowe, gdyby nie obowiązek walki o naszą pozycję międzynarodowa. Jeśli jednak pozostawić tę sprawę na uboczu i ograniczyć się do wewnętrznych stosunków ekonomicznych, to rzeczywiście sprawą główną staje się u nas teraz krzewienie kultury. // Stoimy wobec dwóch najważniejszych zadań, stanowiących o epoce. Jest to zadanie przebudowy naszego aparatu, który absolutnie nic nie jest wart i który przejęliśmy w całości z minionej epoki; przerobić tu czegoś w sposób istotny w ciagu pięciu lat walki nie zdążyliśmy i nie mogliśmy zdążć. Drugie nasze zadanie polega na pracy kulturalnej wśród chłopstwa. A ta praca kulturalna wśród chłopstwa ma za swój cel ekonomiczny właśnie uspółdzielczenie. W warunkach całkowitego uspółdzielczenia stalibyśmy już obiema nogami na gruncie socjalistycznym. Ale to całkowite uspółdzielczenie jest uzależnione od takiego poziomu kulturalnego chłopstwa (właśnie chłopstwa jako olbrzymiej masy), że jest ono niemożliwe bez całej rewolucji kulturalnej. // Nasi przeciwnicy zarzucali nam niejednokrotnie, że zabieramy się do szaleńczej sprawy zaszczepienia socjalizmu w kraju nie dość kulturalnym. Omylili się oni jednak mówiąc, że zaczęliśmy nie od tego końca, od którego należało zacząć według teorii (wszelkich pedantów), i że u nas przewrót polityczny i socjalny wyprzedził ów przewrót kulturalny, ową rewolucję kulturalna, w obliczu której, mimo wszystko, stoimy obecnie. Ta rewolucja kulturalna wystarczy nam teraz do tego, abyśmy się stali krajem w pełni socjalistycznym, ale dokonanie tej rewolucji kulturalnej stawia nas wobec niezmiernych trudności natury zarówno czysto kulturalnej (ponieważ jesteśmy analfabetami), jak i materialnej (ponieważ, by być kulturalnymi, potrzebny jest pewien rozwój materialnych środków produkcji, potrzebna jest pewna baza materialna)" (Lenin 1989, 368-369). 
celu wytworzenie „ludzkich” przesłanek komunizmu. Przy takim ujęciu rewolucji kulturalnej przyświecać musi jakiś projekt przyszłego społeczeństwa, określona wizja przyszłego życia komunistycznego. Z drugiego punktu widzenia rewolucja kulturalna zanurzona jest ściśle w teraźniejszości okresu przejściowego - stanowiąc środek przezwyciężania związanych z nim trudności.

W wypowiedziach Lenina zdecydowanie dominuje drugi punkt widzenia, stąd też Leninowska koncepcja rewolucji kulturalnej nie rozstrzyga aksjologicznych dylematów dotyczących konstrukcji przyszłego społeczeństwa komunistycznego. Co więcej, Lenin łączy rewolucję kulturalną raczej z budową socjalizmu (czy też „podstaw” socjalizmu) niż z przyszłym komunizmem. Rewolucja kulturalna ma być lekiem na panoszący się w Rosji biurokratyzm i katastrofalnie niską kulturę pracy; ma wspierać elektryfikację kraju i uspółdzielczenie wsi; dostarczać nowych, proletariackich kadr kierowniczych, które w przyszłości zastapią wysoko opłacanych/e specjalistów/ki burżuazyjnych/e.

W wypowiedziach Lenina rewolucja kulturalna ujmowana jest więc przede wszystkim jako środek rozwiązywania aktualnych problemów gospodarczych i administracyjnych, jako kluczowy czynnik odbudowy i przebudowy „królestwa konieczności”. Stąd też wizja komunizmu, jaką moglibyśmy wywieść z Leninowskich nawoływań do zmasowanego krzewienia kultury wśród mas, byłaby wizją „kulturalnego” (także w znaczeniu: lekkiego) „królestwa konieczności” (a nie wizją triumfu „królestwa wolności” nad „królestwem konieczności”).

Niemniej jednak Lenin łączy z rewolucją kulturalną oczekiwania, które nie dają się uzasadnić na gruncie koncepcji „kulturalnego” „królestwa konieczności”. Otóż koncepcja ta sugerowałaby dominację kultury technicznej nad kulturą humanistyczną a także - w myśl koncepcji niektórych radzieckich działaczy oświatowych - solidnego kształcenia monotechnicznego, mającego bezpośrednie zastosowanie w praktyce, nad kształceniem politechnicznym, uznawanym niekiedy za bezużyteczną fanaberię. Lenin jest tymczasem obrońcą wykształcenia „ogólnego”, gromiącym działaczy oświatowych, którzy forsują rozwijanie kształcenia monotechnicznego kosztem ogólnego i politechnicznego (Lenin 1988b), a także zwolennikiem krzewienia wśród mas dzieł kultury artystycznej i filozofii.

Innymi słowy, Lenin - choć rozpatruje rewolucję kulturalną przede wszystkim z punktu widzenia interesów rozwoju produkcji i de-biurokratyzacji aparatu zarządzania - jest obrońca i krzewicielem „całej” kultury, wychodząc najwyraźniej z założenia, iż przyszły człowiek, 
socjalistyczny i komunistyczny, jako człowiek wszechstronnie rozwinięty partycypować będzie równomiernie we wszystkich dziedzinach kultury, unikając ,jednostronności” właściwej poszczególnym klasom, warstwom czy grupom zawodowym społeczeństwa kapitalistycznego. W Zadaniach zwiazkón młodzieşy Lenin nakłada na każdego młodego komunistę i każdą młoda komunistkę obowiązek indywidualnego (krytycznego) „przetrawienia” całego dorobku kultury stworzonej przez ludzkość:

Dawna szkoła była szkołą tresury, zmuszała ona ludzi do przyswajania mnóstwa niepotrzebnych, zbędnych, martwych wiadomości, które zaśmiecały umysły i przekształcały młode pokolenie w podciagniętych pod jeden strychulec biurokratów. Popełnilibyście jednak wielki błąd, gdybyście usiłowali wysnuć stąd wniosek, że można stać się komunista, nie przyswoiwszy sobie tego, co nagromadziła wiedza ludzka. Byłoby błędem sądzić, że wystarczy przyswoić sobie hasła komunistyczne, wnioski nauki komunistycznej, nie przyswoiwszy sobie tej sumy wiedzy, której wynikiem jest sam komunizm. Wzorem tego, jak z sumy wiedzy ludzkiej powstał komunizm - jest marksizm (Lenin 1988i, 293).

Komunistą można stać się tylko wtedy, gdy wzbogaci się swą pamięć znajomością całego tego dorobku, który stworzyła ludzkość.

Nie trzeba nam wkuwania, ale pamięć każdego uczącego się musimy rozwinąć i udoskonalić przez znajomość podstawowych faktów, albowiem komunizm [...] przekształci się w pusty szyld, a komunista będzie tylko zwykłym samochwała, jeśli jego świadomość nie przetrawi wszystkich nabytych wiadomości. Powinniście nie tylko przyswoić je sobie, lecz przyswoić tak, aby ustosunkować się do nich krytycznie, nie zaśmiecać umysłu niepotrzebnymi rupieciami, lecz wzbogacić go znajomością wszystkich faktów, gdyż bez takiej wiedzy nie można być współczesnym wykształconym człowiekiem. [...] Jeśli wiem, że wiem mało, to dopnę tego, by wiedzieć więcej; ale jeśli człowiek będzie mówił, że jest komunista i że niczego nie musi znać gruntownie, to w niczym nie będzie podobny do komunisty (Lenin 1988i, 294-295).

\section{Podsumowanie}

Leninowski człowiek komunistyczny ma być, jak wynika z dotychczasowych rozważań, wszechstronnym $/ \mathrm{a}$ inteligentem $/ \mathrm{ka}$, erudyta $/ \mathrm{ka}$, poruszającym $/ \mathrm{a}$ się swobodnie po całym oceanie stworzonej przez ludzkość kultury, harmonijnie łączącym/a zajęcia fizyczne i umysłowe, samodycyplinującym/ą się do pracy siłą zinternalizowanego światopoglądu nakazującego działanie na rzecz dobra ogółu (pracującym/a na miarę swoich zdolności - 
bez zewnętrznego „wspomagania” w postaci dyscypliny ekonomicznej i kontroli administracyjnej, koniecznych w socjalizmie) i panującym/ą nad sobą, tzn. nie dopuszczającym/ą się zachowań aspołecznych. Człowiekowi komunistycznemu przypisuje się trzy atrybuty: zdolność do samodyscypliny pozytywnej, zdolność do samodyscypliny negatywnej, wszechstronność. Dwa pierwsze powiązane są ściśle z dwoma atrybutami społeczeństwa komunistycznego: obowiązywaniem komunistycznej zasady podziału i bezpaństwowością. Podstawowym - najsilniej akcentowanym przez Lenina - atrybutem człowieka komunistycznego, jest zdolność samodyscyplinowania się do pracy: „Komunizmem [...] nazywamy taki porządek, w którym ludzie przyzwyczajają się do wykonywania obowiązków społecznych bez specjalnego aparatu przymusu, kiedy bezpłatna praca dla dobra ogółu staje się zjawiskiem powszechnym”.

Koncepcja ta, jak już sugerowaliśmy, nie jest koncepcją kompletną, tudzież naznaczona jest pewną sprzecznością.

Lenin - słusznie, jak się wydaje - odrzuca utopię komunizmu jako królestwa twórczej pracy niewyalienowanej, „królestwa konieczności”, realizującego - we własnym obrębie, a nie poza swoimi granicami - misję tworzenia ludzi wszechstronnie rozwiniętych. Przyszła praca komunistyczna będzie - na gruncie założeń Lenina - raczej (nieuciążliwa) służbą społeczną niż aktywnością autentycznie samorozwojowa. Przy tym założeniu nie ma nic niepokojącego w Leninowskim postulacie wykorzystania w Rosji elementów systemu taylorowskiego - tak mocno atakowanym na gruncie myśli anarchistycznej (postulat ten, jak wiadomo, nie został w Rosji zrealizowany). Skoro nie chodzi o dezalienację pracy, nie ma nic złego w systemie pracy zwiększającym jej wydajność - przy zachowaniu (a nawet pogłębieniu) zjawiska alienacji, o ile system ten przynosi ludziom pracy określone korzyści. Korzyść, jaką przynosi potencjalnie system taylorowski, przybiera postać alternatywy: albo zwiększenie wolumenu środków konsumpcji, albo zwiększenie zasobów czasu wolnego, przy czym obydwa cele moga być realizowane jednocześnie wedle określonej proporcji. Jak pamiętamy, Lenin właśnie w tekście o tayloryzmie sugeruje skrócenie dnia roboczego do około trzech godzin. Oznaczałoby to nie tylko ilościowe wydłużenie „królestwa wolności”, ale również jakościową zmianę samej koncepcji komunizmu. O ile koncepcja Lenina za kluczowy atrybut człowieka komunistycznego uznaje zdolność samodyscyplinowania się do (dobrej) pracy, a więc za główną formę praxis człowieka przyszłości uznaje komunistyczną pracę, o tyle przy trzygodzinnym dniu pracy człowiek 
komunistyczny nie mógłby być już definiowany (przede wszystkim) jako nosiciel/ka określonego stosunku do pracy, ale (przede wszystkim) jako „obywatel/ka” „królestwa” czasu wolnego, w określony sposób pożytkujący/a ów cenny zasób. Teoria komunizmu powinna być zatem - w pierwszym rzędzie - teorią nowej praxis: „spędzania” czasu wolnego. Przy Marksowskim założeniu, iż człowiek jest (ma być) istotą produkcyjna/twórcza, rozwijająca swoje przyrodzone „zdolności”, „spędzanie” czasu wolnego - produkowanego przez wydajne fabryki pracujące np. w systemie taylorowskim - stanowić musi formę produkcji wytwarzającej (w ostatniej instancji) wszechstronnie rozwinięte osobowości i ciała ludzi komunistycznych. Produkcja tego rodzaju byłaby amatorską twórczością artystyczną, naukową i aktywnością sportową.

Tego rodzaju wniosek stanowiłby logiczne domknięcie koncepcji komunizmu, zakładającej (słusznie, jak sądzimy):

- radykalne skrócenie czasu pracy (a więc niezakładającej dezalienacji pracy, tj. przekształcenia jej w atrakcyjną sferę ludzkiej eksterioryzacji i samorealizacji);

- obumieranie demokracji (ewentualne zachowanie/rozszerzanie demokracji, stanowiłoby marnotrawstwo czasu wolnego, wytworzonego przez wydajne fabryki, który zamiast zasilać „królestwo wolności”, byłby nieproduktywnie trwoniony w „królestwie konieczności”); - imperatyw indywidualnego (krytycznego) „przetrawiania” całego dorobku kultury ludzkiej.

Przyjęcie tego wniosku wymagałoby ponownego przemyślenia innych elementów koncepcji Lenina, w szczególności samodyscypliny pracowniczej (jako atrybutu człowieka komunistycznego) i bezpaństwowości (jako atrybutu społeczeństwa komunistycznego). Nie podejmując w tym miejscu tego problemu, chcielibyśmy zasygnalizować swoje wątpliwości odnośnie do tego, czy, po pierwsze, człowiek żyjący w „królestwie” czasu wolnego musi charakteryzować się zdolnością samodyscyplinowania się do pracy (wydaje się, że przy założeniu, iż praca trwać będzie zaledwie trzy godzinny dziennie, istnienie określonego systemu dyscyplinującego, wymuszającego określoną jakość wykonania, nie będzie dla ludzi komunistycznych rzeczą szczególnie uciążliwa), po drugie, czy przy założeniu, że ludzie żyć będa przede wszystkim w „królestwie wolności”, potrzebna będzie jeszcze (postulowana przez Lenina) „wolność” w znaczeniu bezpaństwowości (atrakcyjnym rozwiązaniem po obumarciu demokracji wydaje się powierzenie zarządzania „królestwem 
konieczności”, a więc materialną bazą „królestwa wolności”, aparatowi złożonemu z hobbystów/ek, pasjonujących się zagadnieniami zarządzania i administrowania).

Wskazując na niekompletność koncepcji Lenina (w gruncie rzeczy brak teorii komunistycznego „królestwa wolności” przy jednoczesnej orientacji na wytwarzanie czasu wolnego), musimy pamiętać o brutalnym kontekście historycznym, towarzyszącym jej powstaniu (katastrofalny rozkład „królestwa konieczności” w pierwszych latach władzy radzieckiej, zagrażający biologicznemu przetrwaniu proletariatu i wysuwający na plan pierwszy zadanie odbudowy „królestwa konieczności”; okoliczność ta nie mogła nie spowodować „zanieczyszczenia” teorii komunizmu, prowadzącego do definiowania komunizmu przede wszystkim jako nowego ustroju „królestwa konieczności”; chęć docenienia pożytecznej inicjatywy „subotników”, sprzyjającej przezwyciężeniu rozprzężenia panującego w „królestwie konieczności”, skłaniała Lenina do definiowania komunizmu jako ustroju opartego na pracy dobrowolnej i bezpłatnej, a zarazem uwikłana była w ówczesne spory ideowe - koncepcja bezpaństwowości komunizmu sformułowana w Państwie a rewolucji może być interpretowana jako rezultat ostrego sporu z ówczesnym reformizmem, popychającego Lenina na pozycje bliskie anarchizmowi (utożsamianie wolności z bezpaństwowościa). 


\section{Wykaz literatury}

Engels, Fryderyk. 1969a. O autorytecie. W Karol Marks, Fryderyk Engels, „Dzieła”, tom 18. Warszawa: Książka i Wiedza.

Engels, Fryderyk. 1969b. Pochodzenie rodziny, własności prywatnej i państwa. W Karol Marks, Fryderyk Engels, „Dzieła”, tom 21. Warszawa: Książka i Wiedza.

Engels, Fryderyk. 1971. Przedmowa do broszury „Artykuty na tematy mięzynarodowe z. crasopisma 'Volksstaat' (1871-1875)”. W Karol Marks, Fryderyk Engels, „Dzieła”, tom 22.

Warszawa: Książka i Wiedza.

Engels, Fryderyk. 1972a. Anty-Dühring. W Karol Marks, Fryderyk Engels, „Dzieła”, tom 20. Warszawa: Książka i Wiedza.

Engels, Fryderyk. 1972b. List do Bebla (18-28 marca 1875 r.). W Karol Marks, Fryderyk Engels, „Dzieła”, tom 19. Warszawa: Książka i Wiedza.

Engels, Fryderyk, i Karol Marks. 1962. Manifest Partii Komunistycżej. W Karol Marks, Fryderyk Engels, „Dzieła”, tom 4. Warszawa: Książka i Wiedza.

Krupska, Nadieżda. 1951. Dyscyplina pionierska. W Nadieżda Krupska, „Wybór pism pedagogicznych". Warszawa: Państwowe Zakłady Wydawnictw Szkolnych.

Lenin, Włodzimierz. 1951. Państwo a rewolucja. W Włodzimierz Lenin, „Dzieła wybrane”, tom 2. Warszawa: Książka i Wiedza

Lenin, Włodzimierz. 1985. Krok naprzód, dwa kroki wstecz (Kryzys w naszej partii). W Włodzimierz Lenin, „Dzieła wszystkie”, tom 8. Warszawa: Książka i Wiedza.

Lenin, Włodzimierz. 1987. System Taylora - ujarzmienie człowieka przez maşyne. W Włodzimierz Lenin, „Dzieła wszystkie”, tom 24. Warszawa: Książka i Wiedza.

Lenin, Włodzimierz. 1988a. Driecięca choroba „lewicowości” w komuniżie. W Włodzimierz Lenin, „Dzieła wszystkie”, tom 41. Warszawa: Książka i Wiedza.

Lenin, Włodzimierz. 1988b. O ksztatceniu politechnicznym. Notatki w zwiazku z tezami Nadieżdy Konstantinowny. W Włodzimierz Lenin, „Dzieła wszystkie”, tom 42. Warszawa: Książka i Wiedza.

Lenin, Włodzimierz. 1988c. Od pierwszego subotnika na kolei moskiewsko-kazańskiej do wszechrosyjskiego pierwszomajowego subotnika. W Włodzimierz Lenin, „Dzieła wszystkie”, tom 41. Warszawa: Książka i Wiedza.

Lenin, Włodzimierz. 1988d. Od z̧burzenia odwiecznego układu ku tworženiu nowego. W Włodzimierz Lenin, „Dzieła wszystkie”, tom 40. Warszawa: Książka i Wiedza.

Lenin, Włodzimierz. 1988e. Pierwotny wariant artykułu „Najbližsze zadania władzy radrieckiej”. W Włodzimierz Lenin, „Dzieła wszystkie”, tom 36. Warszawa: Książka i Wiedza.

Lenin, Włodzimierz. 1988f. Pierwszy wszechrosyjski zjazd poświęcony sprawom oświaty pozaszkolnej. 6-19 maja 1919 r. 2. Przemówienie o oszukiwaniu ludu basłami wolności i równości 19 maja. W Włodzimierz Lenin, „Dzieła wszystkie”, tom 38. Warszawa: Książka i Wiedza.

Lenin, Włodzimierz. 1988g. Referat o subotnikach wygłoszony na Moskiewskiej Ogólnomiejskiej Konferencji RKP(b) 20 grudnia $1919 r$. W Włodzimierz Lenin, „Dzieła wszystkie”, tom 40. Warszawa: Książka i Wiedza.

Lenin, Włodzimierz. 1988h. Wielka inicjatywa (O bohaterstwie robotników na zapleczu. Z okazji „,komunistycznych subotników”). W Włodzimierz Lenin, „Dzieła wszystkie”, tom 39. Warszawa: Książka i Wiedza.

Lenin, Włodzimierz. 1988i. Zadania zwiazków młodzieży (przemówienie na III W szechrosyjskim Zjeździe Rosyjskiego Komunistycznego Zwiqzku Mtodzieży 2 października 1920 r.). W Włodzimierz Lenin, „Dzieła wszystkie”, tom 41. Warszawa: Książka i Wiedza. 
Lenin, Włodzimierz. 1989. O spółdzielczości. W Włodzimierz Lenin, „Dzieła wszystkie”, tom 45. Warszawa: Książka i Wiedza.

Lordon, Frédéric. 2012. Kapitalizm, niewola i pragnienie. Marks i Spinoza. Tłum. Magdalena Kowalska, Michał Kozłowski. Warszawa: Instytut Wydawniczy Książka i Prasa.

Marks, Karol. 1962. Nędza filozofii. W Karol Marks, Fryderyk Engels, „Dzieła”, tom 4. Warszawa: Książka i Wiedza.

Marks, Karol. 1966. Teorie wartości dodatkowej. Cz̧śś trzecia. Tłum. Julian Maliniak. Warszawa: Książka i Wiedza.

Marks, Karol. 1968. Kapitał. Tom I. W Karol Marks, Fryderyk Engels, „Dzieła”, tom 23. Warszawa: Książka i Wiedza.

Marks, Karol. 1972. Krytyka Programu Gotajskiego. W Karol Marks, Fryderyk Engels, „Dzieła”, tom 19. Warszawa: Książka i Wiedza.

Marks, Karol. 1976. Rekopisy ekonomiczno-filozoficzne z 1844 r. W Karol Marks, Fryderyk Engels, „Dzieła”, tom 1. Warszawa: Książka i Wiedza.

Marks, Karol. 1981. Teorie wartości dodatkowej. Cz̨eść druga. W Karol Marks, Fryderyk Engels, „Dzieła”, tom 26, część 2. Warszawa: Książka i Wiedza.

Marks, Karol. 1983. Kapitat. Tom III. Cześś pierwsza. W Karol Marks, Fryderyk Engels, „Dzieła”, tom 25, część 1. Warszawa: Książka i Wiedza.

Marks, Karol. 1984. Kapitał. Tom III. Cześć druga. W Karol Marks, Fryderyk Engels, „Dzieła”, tom 25, część 2. Warszawa: Książka i Wiedza.

Marks, Karol. 1986. Zarys krytyki ekonomii politycznej. Tłum. Zygmunt Jan Wyrozembski. Warszawa: Książka i Wiedza.

Strumilin, Stanisław. 1962. Dzień pracy a komunizm. W Stanisław Strumilin, „Problemy socjalizmu i komunizmu w ZSRR”. Tłum. Zbigniew Dąbrowa, Jan Lenart, Mina Michlewicz, Julia Mincowa, Edward Nabiel. Warszawa: Państwowe Wydawnictwo Ekonomiczne.

Walicki, Andrzej. 1996. Marksižm i skok do królestwa wolności. Drieje komunistycznej utopii. Warszawa: PWN. 
Florian Nowicki - ur. w 1980 r., związany z Zakładem Filozofii Społecznej IF na WFiS UW. W IF na WFiS UW obronił pracę doktorską (pod kierunkiem prof. Aleksandra Ochockiego) Społeczne znaczenie płci w marksistowskiej teorii historii. Zajmuje się filozofią społeczna, antropologia, aksjologia, historią marksizmu, problematyka gender na gruncie marksizmu. Działacz Komisji Operatorów Żurawi Wieżowych OZZ Inicjatywa Pracownicza.

\section{DANE ADRESOWE}

Instytut Filozofii UW

Krakowskie Przedmieście 3

00-927 Warszawa

E-MAIL: n.florian@poczta.onet.pl

CYTOWANIE: Nowicki, Florian. 2016. Samodyscyplina i wszechstronność - człowiek komunistyczny w ujęciu Lenina. Praktyka Teoretyczna 2 (20). 142-180.

DOI: $10.14746 /$ prt.2016.2.5

\section{AUTHOR: Florian Nowicki}

TITLE: Self-discipline and Versatility - the Lenin's Communist Man

ABSTRACT: The article is devoted to the concept of the communist man that emerges from the writings of Vladimir Lenin. The author emphasizes that it is an incomplete concept, and therefore ambiguous - provoking us to fill its "gaps" with material that does not refer directly to the issue of a communist society. The reconstruction in this article follows two concepts: self-discipline and versatility. However, the proposed distinction between positive and negative self-discipline is here of a great importance. Through positive general selfdiscipline the author understands self-discipline as work for the greater good of society, with the key area of this kind self-discipline being the realm of work. It is therefore mainly a selfdisciplined work - necessary due to the absence of mechanisms of economic coercion under communism (embodying the principle of the distribution according to ones needs, rather than ones labor input). By negative self-discipline the author understands refraining from acts that are harmful to society, that is, so-called "excesses" - a necessary element due to the stateless nature of a communist society. Self-discipline (positive and negative) is correlative to communist negative freedom, which consists (in Lenin' $s$ terms) of the absence of any external mechanisms of discipline and thus any "management" of people (even if ultrademocratic in character). In turn, characterizing the Leninist understanding of the postulate of versatility, the author cites, among others, the concept of polytechnic education 
(put forward by Marx and developed by Nadezhda Krupskaya), the problem of "intelligentsialization" of the proletariat, and therefore the postulate of the assimilation by the proletariat of the positive qualities of the intelligentsia (the extent of its horizons, the capacity for the independent and critical "survival" of humanity's cultural heritage), however separated from its negative traits (lack of teamwork skills).

KEYWORDS: communism, communist man, socialism, Marx, Lenin, Krupskaya, work, leisure, liberty, kingdom of freedom. 